\title{
Solar Thermal Test Facility Experiment Manual
}

David M. Darsey, John T. Holmes, Larry O. Seamons, Dean J. Kuehl, David B. Davis, John M. Stomp,

Larry K. Matthews, John V. Otts

Prepared by Sandia Laboratories, Albuquerque, New Mexico 87115 and Livermore, California 94550 for the United States Department of Energy under Contract AT(29-1)-789

Printed October 1977

\section{Sandia Laboratories}




\section{DISCLAIMER}

This report was prepared as an account of work sponsored by an agency of the United States Government. Neither the United States Government nor any agency Thereof, nor any of their employees, makes any warranty, express or implied, or assumes any legal liability or responsibility for the accuracy, completeness, or usefulness of any information, apparatus, product, or process disclosed, or represents that its use would not infringe privately owned rights. Reference herein to any specific commercial product, process, or service by trade name, trademark, manufacturer, or otherwise does not necessarily constitute or imply its endorsement, recommendation, or favoring by the United States Government or any agency thereof. The views and opinions of authors expressed herein do not necessarily state or reflect those of the United States Government or any agency thereof. 


\section{DISCLAIMER}

Portions of this document may be illegible in electronic image products. Images are produced from the best available original document. 
Issued by Sandia Laboratories, operated for the United States Department of Energy by Sandia Corporation.

\section{NOTICE}

This report was prepared as an account of work sponsored by the United States Government. Neither the United States nor the United States Department of Energy, nor any of their employees, nor any of their contractors, subcontractors, or their employees, makes any warranty, express or implied, or assumes any legal liability or responsibility for the accuracy, completeness or usefulness of any information, apparatus, product or process disclosed, or represents that its use would not infringe privately owned rights.

Printed in the United States of America

Available from

National Technical Information Service

U. S. Department of Commerce

5285 Port Royal Road

Springfield, VA 22161

Price- Printed Copy $\$ 4.50$; Microfiche $\$ 3.00$ 


\section{PAGES 1 to 2 WERE INTENTIONALLY LEFT BLANK}


SAND 77-1173

Unlimited Release

Printed October 1977

SOLAR THERMAL TEST FACILITY EXPERIMENT MANUAL

David M. Darsey

Facilities/Test Equipment Design and

Development Division 9344

$$
\begin{gathered}
\text { John T. Holmes } \\
\text { Larry O. Seamons } \\
\text { Dean J. Kuehl } \\
\text { David B. Davis } \\
\text { John M. Stomp } \\
\text { Larry K. Matthews } \\
\text { John V. Otts }
\end{gathered}
$$

Solar Thermal Test Facility Division 5713

Sandia Laboratories

Albuquerque, NM 87115

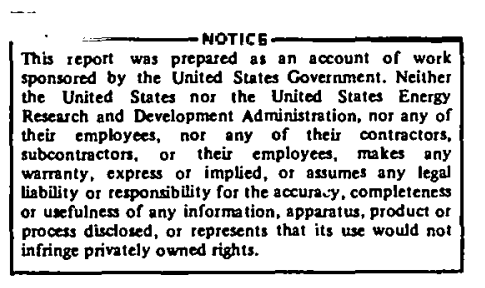


I. Introduction $\quad$. $\quad 7$

II. Administrative Processes 9

A. Experiment Implementation $\quad 10$

B. STTF Experiment Coordination Office 11

C. STTF Users Association $\quad 12$

D. Experiment Operation $\quad 12$

E. Scheduling 13

F. Responsibilities and Charges to Experimenters $\quad 13$

G. Access to KAFB and the STTF 15

III. Description of STTF Capabilities and Interfaces $\quad$. 18

A. Heliostat Array Subsystem ' 18

B. Focus and Alignment Subsystem (FASS) . . . . 21

C. Working Receiver $\quad 21$

D. Real Time Aperture Flux System 23

E. Computerized Heliostat Beam Model . . 23

F. ST'L 'Tower . . . . $\quad 25$

G. Data Recording and Control . 33

H. Meteorological System $\quad$. . 37

I. Administration and Control Building 39

J. Asșembly Building . 40

IV. Requirements of Experimenters · . . 42

A. Data Package . . . . 43

B. Codes and Standards : $\quad: \quad 45$

C. Test Plan $\quad \because \cdots 46$

D. Detailed Procedures and Training Materials 47

E. Quality Asșurance Records 48

F. Shipping and Receiving $\quad 49$

G. Results and Reports . 


\section{ILLUSTRATIONS}

$\underline{\text { Figure }}$

$\underline{\text { Page }}$

1 Solar Thermal Test Facility $\quad 8$

2 Location of Solar Thermal Test Facility, KAFB 16

$3 \quad$ Martin Marietta Heliostat Array $\quad 18$

4 STTF Heliostat Layout $\quad 19$

$5 \quad 1 \mathrm{MW}$ Working Receiver $\quad 22$

6 Nominal Tower Cross Section 25

7 Nominal Tower Cross Section at 200-Foot Level $\quad 25$

8. Nominal Tower Cross Section at Ground Level 28

$9 \quad$ North Tower Elevation Showing Test Bays 28

10 Simplified Schematic, Heat Rejection System 32

TABLES

Table

I Experiment Review Hrocess $\quad$ / 11

II 78 Heliostats, Zone A, Aimed at Target in 140-Foot Test Bay 26

III 222 Heliostats, Zone A, Aimed at Tower Top Receiver 27

IV Requirements for Experimenters

42 


\section{SOLAR THERMAL TEST FACILITY EXPERIMENT MANUAL}

\section{CHAPTER I. INTRODUCTION}

The Solar Thermal Test Facility (STTF) is operated for the Department of Energy (DOE) by Sandia Laboratories to advance the development of solar thermal electric power to a commercial scale. The STTF (Figure 1), with a thermal collection capability of about 5 megawatts, is designed to perform a variety of functions including, but not limited to, the following:

1. Testing scale models of water cooled receivers (boilers) for a $10 \mathrm{MW}$ demonstration pilot plant and commercial plants of the future.

2. Testing prototype collectors (heliostats) for the $10 \mathrm{MW}$ pilot plant and future plants.

3. Testing components and subsystems for advanced solar thermal systems including heat storage and gas or liquid metal cooled receivers.

4. Development of high temperature chemical and metallurgical processes and determination of high temperature (solar spectrum) effects on materials.

5. Testing instrumentation systems needed for the commercialization of solar energy.

6. Training personnel to operate solar facilities.

This document provides information on administrative procedures, the rapabilitics of tle STTF, and the reyuirements of the experimenter. This document will be revised periodically to reflect the capabilities of the facility and needs of the experimenters.

Experimenters with projects that are under direct DOE programmatic contracts will work directly with the STTF Experiment Coordination Office (ECO). Correspondence should be addressed to:

STTF Experiment Coordination Office

Division 5713, T-27

Sandia Laboratories

Albuquerque, NM 87115

Commercial 505-264-2280

FTS

$475-2280$ 


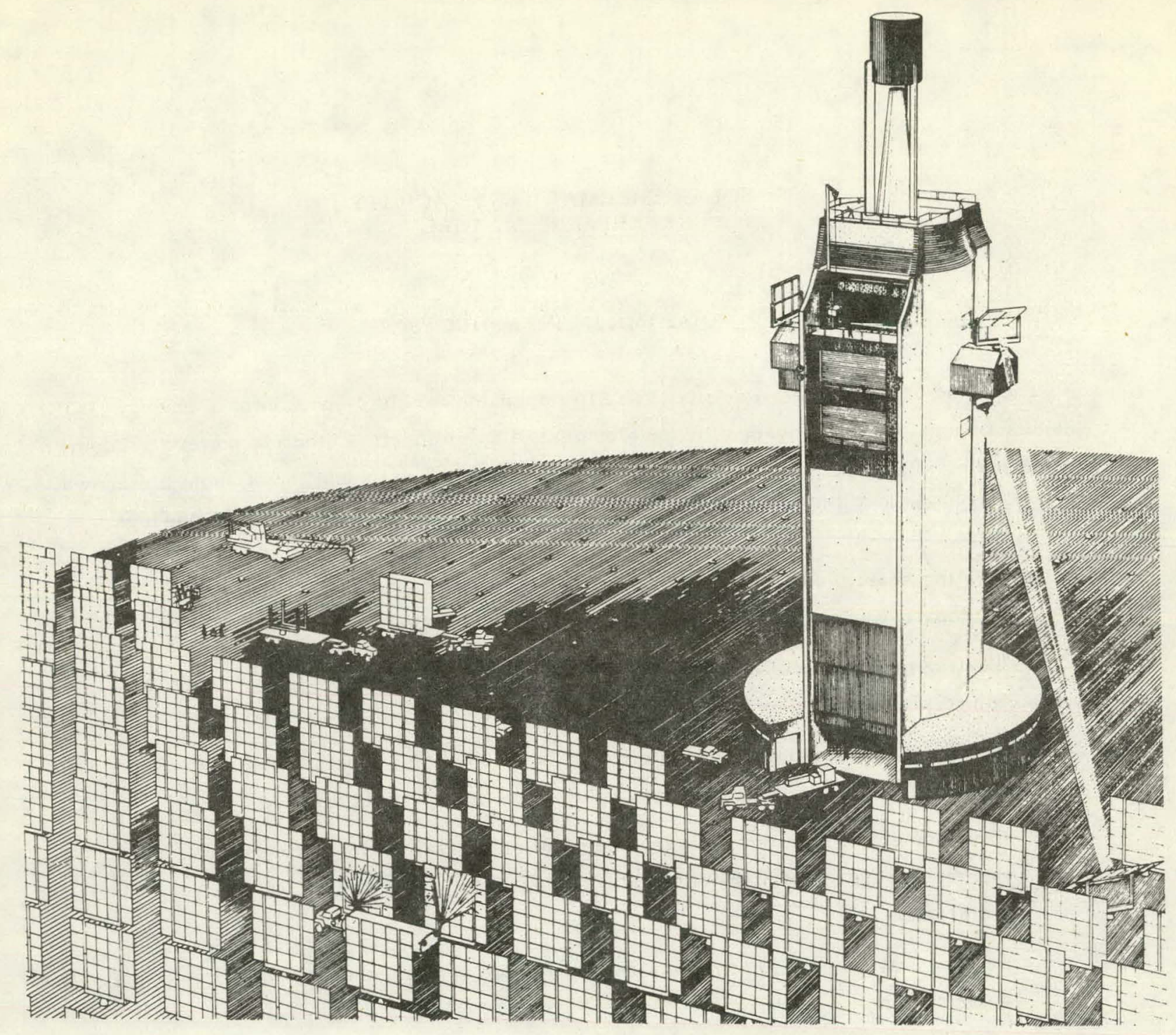

Figure 1. Solar Thermal Test Facility

Other experimenters interested in using the facility should direct inquiries to the STTF Users Assnriation at:

Solar Thermal Test Facility Users Association

Suite 1507, First National Bank Building, East

Albuquerque, NM 87108

Commercial 505-268-3994 


\section{CHAPTER II. ADIVINISTRATIVE PROCESSES}

There are two routes that experimenters may follow in implementing experiments at the STTF. Experimenters with major DOE programmatic projects (Route 1) will work directly with the STTF Experiment Coordination Office (ECO). Other experimenters will work initially with the STTF Users Association (Route 2) which will review, coordinate, and set priorities for these experiments. Initial contacts with either organization need only to include a brief description of the experiment and definition of the testing requirements.

When these initial contacts indicate that the experiment is feasible, the experimenter will be asked to prepare a brief written proposal and submit two copies to the STTF-ECO for Route 1 experiments or the Users Association for Route 2 experiments. The proposal shall cover:

1. The objective of the experiment.

2. A description of the experimental equipment including STTF interface requirements.

3. Space, utilities, and services required including a brief definition of:

a. Flux required.

b. Thermal power required.

c. Cooling needs.

d. Instrumentation and control requirements.

e. Facility data requirements:

f. Special safety precautions or safety features.

g. Thermal protection requirements.

h. Beam diagnostic needs

4. Time estimate for set-up, operation, and removal including the desired time frame for testing.

5. An estimate of financial assistance, if necessary. 1

If technically feasible and appropriate for testing at the STTF, a probable time frame for testing will be established by the STTF Project Director relative to other current and proposed experiments and facility capabilities. When a Route 2 experiment has been. approved by the Users Association, the experimenter will be put in direct contact with the STTF-ECO for the details of

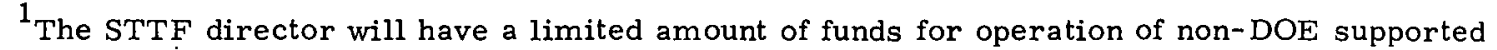
experimenters (see II F). The UA will not, at present, fund hardware developments, but may be able to provide limited financial aid for experiment delivery, installation, and travel to the STTF. 
implementing his experiment. The STTF-ECO will provide the experimenter details of facility capabilities, interfaces, safety policies, and other requirements. The ECO will also assist the experimenter in designing special interfaces. The functions of the ECO are outlined in detail in Section II, Part B.

\section{A. Experiment Implementation}

Implementing an experiment at the STTF necessitates strong and direct interactions between the experimenters and the STTF staff to assure that experiments are carried out in a systematic and timely manner. The experimenter will be required to supply detailed information to the STTF so that the experiment can he installed and opcrated safely dud rellabiy to obtain desired test conditions and results.

To document an approved experiment, the experimenter shall develop and submit five copieo of a Data Package and T'est Plan to the STTF for revlew and approval. The amount of detail required will depend on the nature of the experiment. It is possible that one or more iterations of these submittals will be required prior to their final approval by the STTF Project Director. The experimenter should normally start construction of his hardware only after the Data Package is approved. Earlier construction shall be at his own risk since STTF reviews may require significant changes. At the time approval is given, the STTF Project Director will also assign a preliminary test schedule for the experiment.

At least 60 days prior to the scheduled installation date at the STTF, the experimenter shall provide two copies of any detailed input to the ECO on operating, maintenance, training, and quality assurance (QA) procedures that may be required.

At least 30 days prior to shipping his expcriment to the STTF site, the experimenter shall submit his QA Records (as-built drawings and QA records) for a final ECO review and approval.

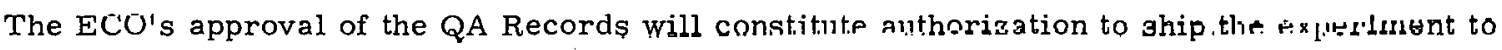
the STTF. Approval or disapproval to ship will be granted within 15 days of receipt of the $Q A$ Recurds.

A summary of the normal times required for reviowo and apprividis of the various experimenter inputs is given in Table $\mathrm{I}$. 


\section{TABLE I}

Experiment Review Process

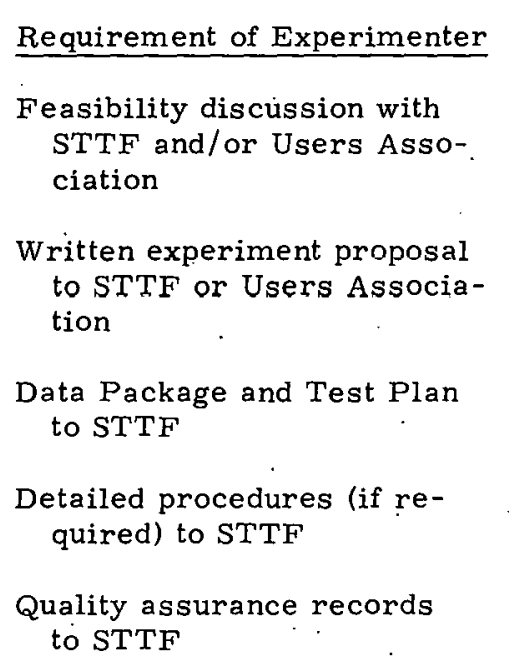

Time Required for Review and Approval

1 week

$$
\begin{aligned}
& \text { 2-8 week.s } \\
& \text { 6-8 weeks per } \\
& \text { iteration } \\
& \text { 4-8 weeks } \\
& 2 \text { weeks }
\end{aligned}
$$

\author{
Result to Experimenter \\ Feasibility determined, \\ test time frame \\ established \\ Experiment approved, \\ preliminary test \\ schedule \\ Test scheduled \\ Procedures approved \\ Authorization to ship \\ hardware to STTF
}

\section{B. STTF Experiment Coordination Office}

The STTF will provide engineering services to experimenters through the Experiment Coordination Office (ECO). The ECO is comprised of the STTF engineering and operations staff. The scope of these ECO services include:

1. Provide information on STTF capabilities, controls, data systems, and safety requirements.

2. Provide design data on STTFF/experiment interfaces.

3. Consult with experimenters on their designs for mounting and interface hardware. Experimenters will normally provide all connections to existing STTF systems and utilities.

4. Review experimenter's Data Package and Test Plan.

5. Provide detailed test planning to assure that test conditions and data requirements are met.

6. Translate experimenter's procedural input into STTF operating procedures and sequénces.

7. Provide special safety equipment and procedures to assure overall facility safety.

8. Provide data reports and a limited amount of data processing and analysis.

9: Provide summary reports on the operation and control of the experiment. 


\section{STTF Users Association}

The STTF Users Association is an organization of scientists and engineers that includes representatives of the national-laboratories, research institutes, private utilities, industrial corporations, universities, and others interested in use of the STTF.

The STTF Users Association has the following gerie!.*al purposeg:

1. To act as a point of contact and primary access link for Route 2 experimenters and the STTF.

2. To solicit and review proposals, and make recommendations to DOE regaluling the utilization of the STTF for Route 2 experiments.

3. Tu disseminate STTF information on a regular badia; and

4. To provide funding for testing Route ? experiments, subjẹct lo I II I: program àpproval.

The STTF Users Ássociation san be contacted tlirough its Executive Director:

Executive Director

STTF Users Association

Suite 1507, First Natiunal Bank Building, East

Albuquerque, NM 87108

Phone 505-268-3994

\section{Experiment Operation}

Many types of experiments are expected to he propoocd for the STTF. Some will be very complex and will have strong interfaces with the STTF systems. Such experiments will normally be operated by the STTF staff with close coordination and advice provided by the resident experimenter. Similar experiments, such as instruments, material tests, etc. may be operated by the resident experimenter. In all cases, the STTF: stuff will opcrate the mafor 'S"I'F' systems and diagnostic tools. The STTF staff will be responsible for facility safotyr. The exacl ivle of the experimenter in operations will be determined during reviews of the Data Package and Test Plan.

The facility has the floubilit. ful chuging and tailuring the flux or other operating conditions in real time. The bounds on permitted changes are related to facility safety operability and will be defined during detailed test planning between the experimenter and the ECO. Other deviations from the test plan during actual operation will require approval by the ECO Test Engineer and the STTF Safety Officcr assigited to the test. 


\section{E. Scheduling}

Scheduling is the responsibility of the STTF Project Director. Input from the experimenter and advice from the STTF Experiment Coordination Office (ECO), DOE/DSE, and the STTF Users Association will be conșidered when scheduling experiments. The experimenter will be notified of the tentative schedule for his experiment when the experiment proposal is approved. The detailed test schedule will be worked out during the review of the experimenter's Data Package and Test Plan.

\section{F. Responsibilities and Charges to Experimenters}

Funding of the general operation and maintenance of the STTF will be provided by DOE/DSE. A memorandum of understanding will be developed by Sandia to define the Sandia/DOE/Experimenter/ Users Association funding and responsibility relationships through the DOE Albuquerque Operation Office.

For DOE-sponsored experiments, Sandia will. normally furnish the following materials and services without charge:

1. Technical coordination, consultation, and reviews of experimenter inputs.

2. Design assistance for experiment interfaces.

3. Instrument and data system hook-up, check-out, and operation, including real time data displays, data recording, and a limited amount of data reduction.

4. Space and nornal utilities for the experiment.

5. Heat rejection system operation.

6: Elevating module and crane operation.

7. Office and assembly or set-up space.

8. Working heliostat field operation tailored to the needs of the experiment.

9. Safety coordination.

10. Operations of diagnostic and calibration facilities including:

a. Heliostat focus and aligniment system.

b. Meteorological system.

c. Real time aperture flux meàsuring system.

d. $1 \mathrm{MW}_{\mathrm{t}}$ low temperature, water cooled working receiver.

11. Data and operations reports. 
Normally the experimentcrs will have the following responsibilities:

1. Delivery of experiment to the STTF.

2. Provide final assembly of experiment at the STTF.

3. Install data and control system to STTF computer and data acquisition interfaces.

4. Provide data package, test plan, and other requirements outlined in Chapter IV.

5. Design, procure, and provide all mechanical, structural, and electrical interfaces required for experiment installation and operation.

6. Provide fur expériment disassembly and final dispnsition.

7. Provide for data analysis, and interpretation, and write tcot reports,

A number of items will require negotiation regarding the respoltsible party and funding source for the work. The result of the negotiation will be summarized in the document of understanding. These negotiable items include:

1. Experiment installation and check-out including required labor, special equipment, and supplies.

2. Experiment control method:

a. Use of 3TTF computers for-control.

b. Use of experimenter supplied controls.

3. Experiment operation responsihilities and intcrfaces.

The STTF Project Director will also have the discretion of providing similar services up to a $\$ 10,000$ value to non-DOE funded (including foreign experimenters) experimenters. Non-DOE/ DSE funded experiments will be required to negotiate a cost reimbursement agreemcnt with $\mathrm{DOE} /$ ALO for experiments expected to exceed $\$ 10,000$ in operational cost.

The following services, if provided, will normally require cost reimbursement by all experimenterg:

1. Design and engineering services for major plant modifications or interfaces required for certain experiments.

2. Components and services supplied by the STTF required to remedy, repair, or replace defective or malfunctioning components in an experiment. Spare parts are the responsibility of the experimenter.

\footnotetext{
* Major STTF modifications (new permanent facilities such as gas or liquid metal heat rejection systems, thermal storage systems, etc.) normally will be funded from DOE construction budget and will require the normal proposal/approval sequence for line items.
} 
3. Data logging or analysis equipment or supplies in addition to the current capabilities of the STTF.

4. Special services requiring paid overtime effort.

5. Computing time on Sandia's CDC computer facilities.

To cover charges for these services to DOE experimenters or general charges over $\$ 10,000$ for non-DOE experimenters, the experimenter must submit a statement of work and request for estimate to:

Director, Special Programs Division

DOE Albuquerque Operations Office

P. O. Box 5400

Albuquerque, New Mexico 87115

with a copy to the STTF Project Director. The experimenters contract number and the contracting officer, address, and telephone number should be included for all government funded programs.

The experimenter will receive a cost estimate (not a quotation), and he shall then proceed to submit a funding document (purchase order, etc.) to DOE. When DOE authorizes the funds to Sandia, the services will be provided in accordance with the document of understanding and the assigned scheiule.

G. Access to KAFB and the STTF

The STTF is located on Kirtland Air Force Base (KAFB). Visitors must inform the STTF of their expected arrival time so that arrangements can be made for KAFB visitor passes. A security clearance will normally not be required.

When the visitor arrives at either the Gibson or Wyoming entrance to KAFB, he shall identify himself and provide the Security Police with the name of his STTF contact. Visitors will be required to observe all posted traffic regulations while on KAFB. Figure 2 shows the location of the . STTF relative to other prominent features at Sandia Laboratories and KAFB.

A receptionist will greet all visitors arriving at the STTF Administration Building: Any access problems should be addressed to the STTF Project Director, 505-264-2280.

Private cameras will be permitted at the STTF site, but cannot be taken into Sandia or KAFB security areas.

Resident experimenters will be required to sign the following experimenters agreement prior to becoming resident at the STPF. 


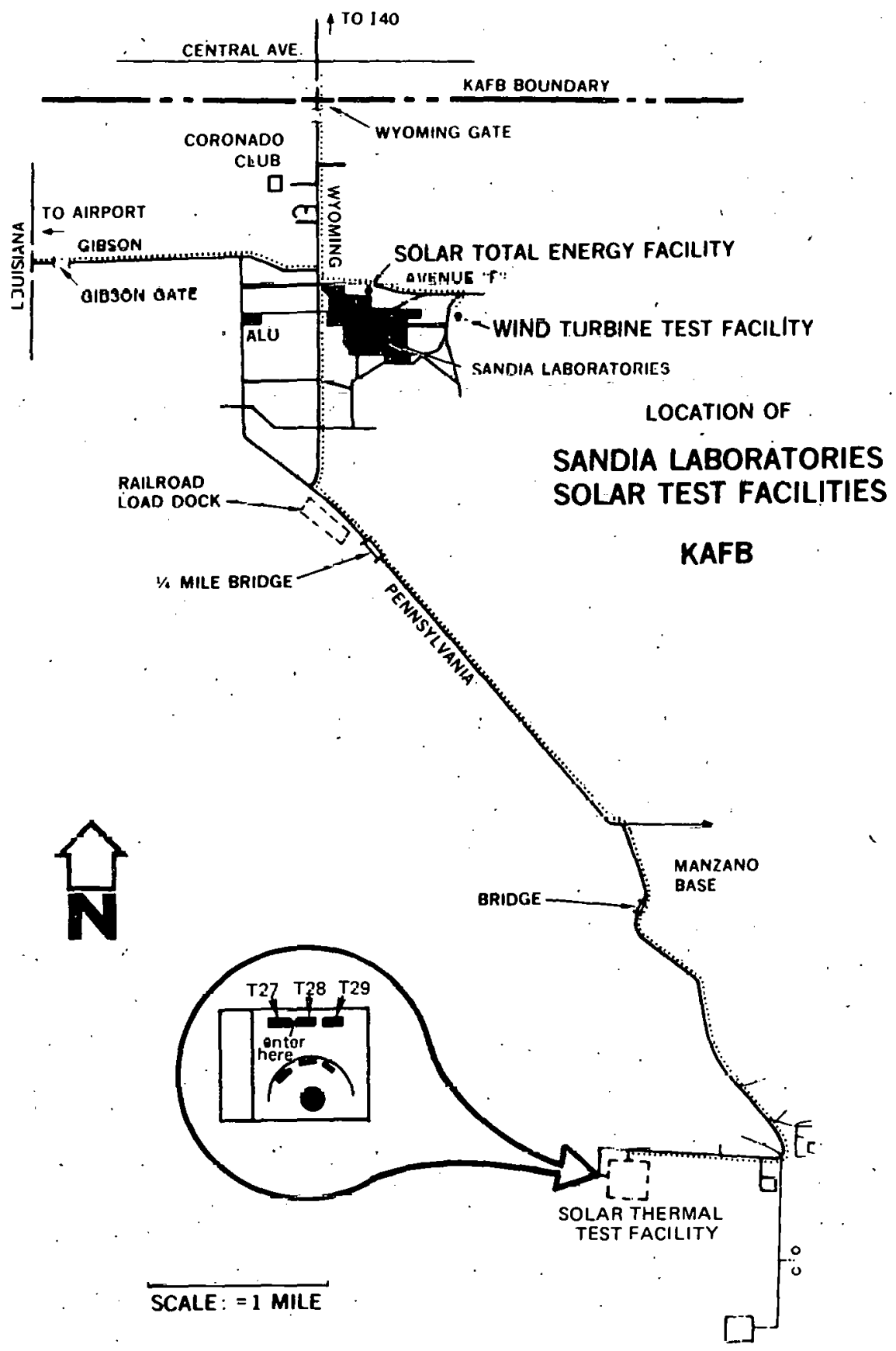

Figure 2. Location of Solar Thermal Test Facility, KAFB 


\section{SANDIA LABORATORIES \\ SOLAR THERMAL TEST FACILITY \\ RESIDENT EXPERIMENTER AGREEMENT}

A. RULES AND REGULATIONS

I agree to observe and conform to all rules and regulations including security, health, and safety rules presently in effect at Sandia or Kirtland AFB or as they may be amended from time to time.

B. RELEASE

I hereby covenant and agree for myself, my heirs, successors, administrators, executors, and assigns to release the United.States of America, including DOE arid Sandia and their officers, agents, and employees from all liability for any personal injuries (including death) to me or for damage to any of my property which may arise out of my access to the STTF and the use of its facilities unless it shall be determined that such injury or damage was caused directly by gross negligence or wilful misconduct on the part of an officer. employee, or agent of Sandia or the United States of America, including DOE.

Date Signed Signature

Citizen of Experimenter Name

Parent Organization

Dates of Residence, From To

STTF Contact

Purpose of Regidence 


\section{CHAPTER II. DESCRIPTION OF STTF CAPABILITIES AND INTERFACES}

'I'his section describes the general capabilities and interfaces that will be of interest to experimenters. Additional details of the design and capabilities of STTF systems will be available through the Experiment Coordination Office (ECO). This section of the Manual will be revised periodically to reflect current STTF capabilities.

\section{A. Holiogtat Nrray Jubsyslem}

The STTF energy collection field will initially consist of 2.22 heliootats (Figule 3). The totul hellostat field is capable of concentrating in excess of 5 million thermal watts of power under optimum sun, heliostat, and target conditions. For test flexibility heliostats may be located on either of two general foundation arrays which form a northern and annular distribution with respect to the tower center (Figure 4).

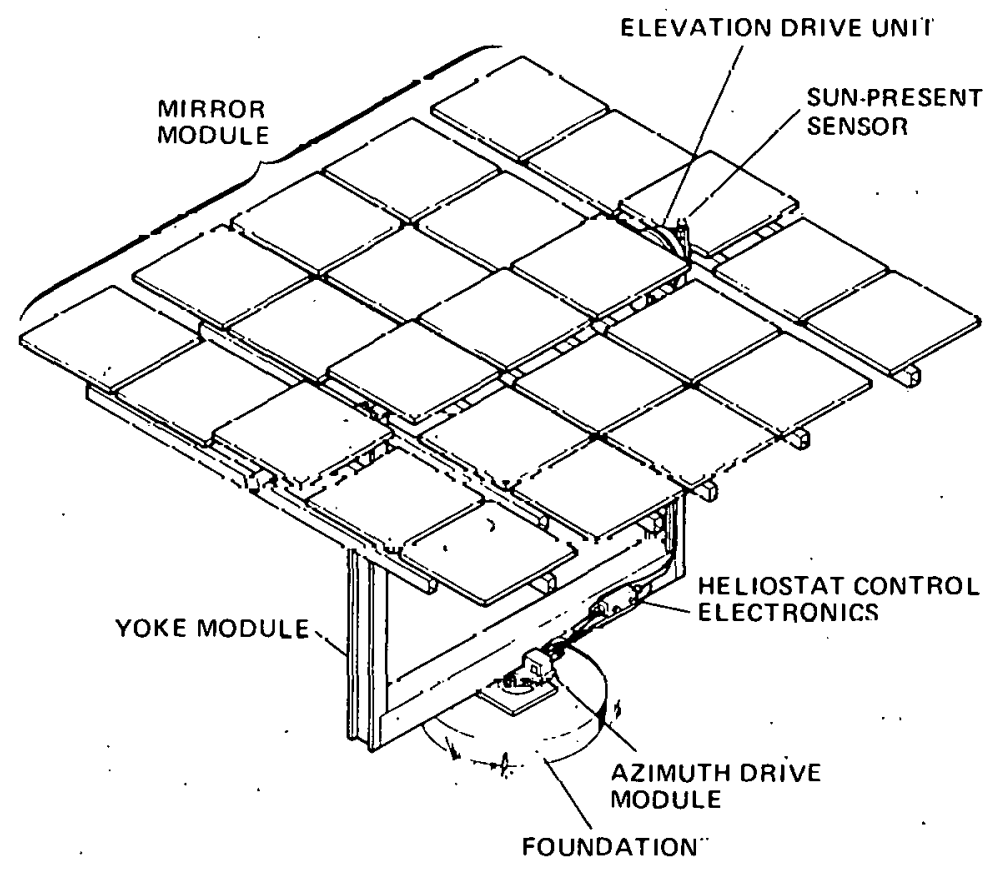

Figure 3. Martin Marietta Heliostat Array 


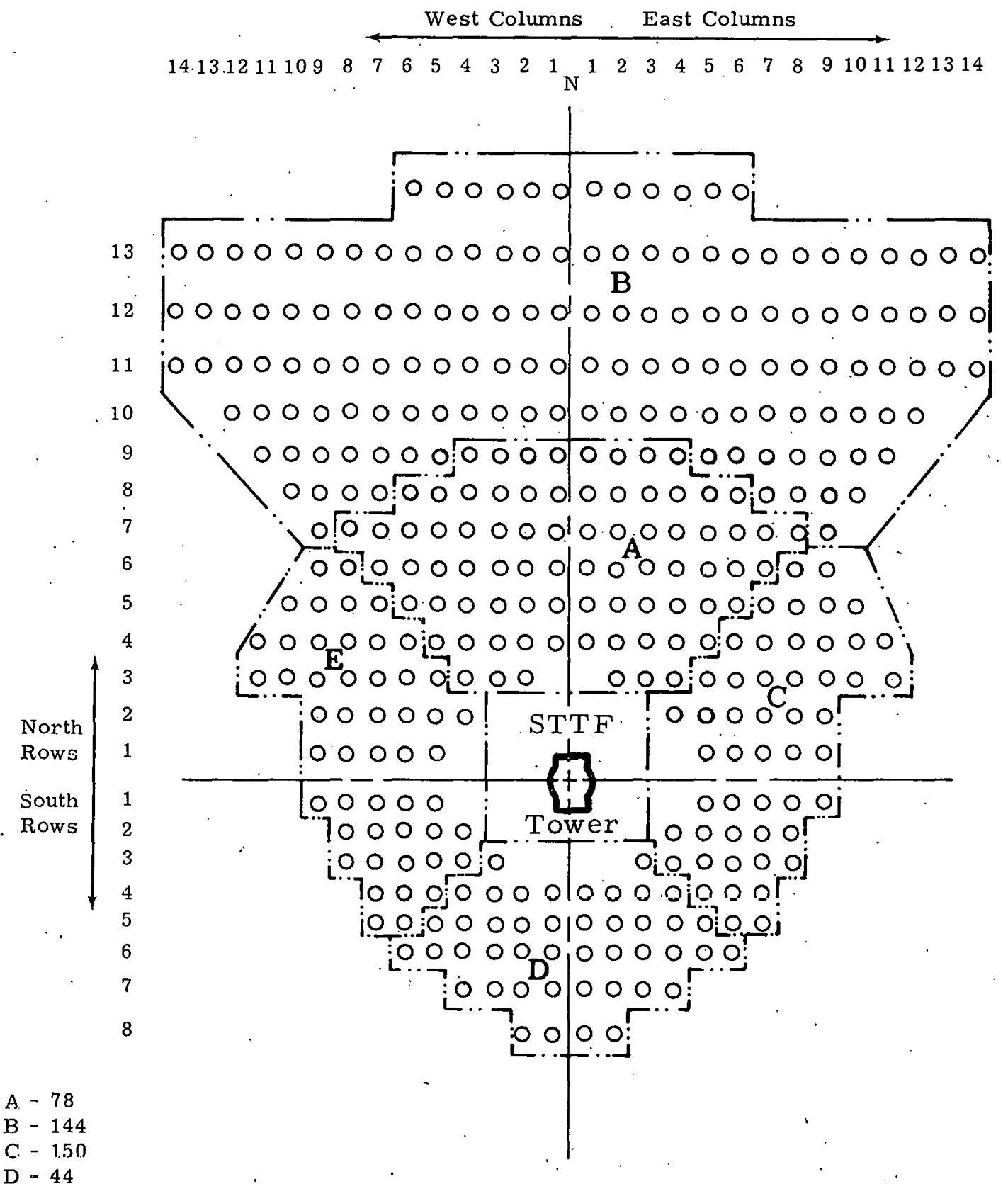

Figure 4. STTF Heliostat Layout 
The maximum theoretical temperature obtainable at the STTF can be found using the following procedure:

At steady state the heat input to an object in the beam is equal to the heat loss. At high temperatures, radiation is the dominant mode of heat transfer.

$$
\alpha Q=\epsilon \sigma\left(T^{4}-T_{a}^{4}\right)
$$

or

$$
T=\left[\frac{\alpha Q}{\epsilon \sigma}+T_{d}^{4}\right]^{1 / 4}
$$

This also assumes heat loss is to a large spacc (not a silull ronm). 'l'bereforc, the geometric configuration factor is approximately 1.

The STTF can achieve approximately $2500 \mathrm{~kW} / \mathrm{m}^{2}$ maximum with 222 heliostats under the best conditions. Assuming a body where $\epsilon \doteq \alpha$ and $\mathrm{T}_{\mathrm{a}}=300^{\circ} \mathrm{K}$. The equation for temperature gives:

$$
\mathrm{T}=2570^{\circ} \mathrm{K}=2297^{\circ} \mathrm{C}=4626^{\circ} \mathrm{R}=4166^{\circ} \mathrm{F}
$$

Caleuiatèd flux maps are presented in a later section of this chapter.

Each heliostat has 25 mirror facets that total 400 square fect of reflectlve surface per heliostat. The mirror facets are mechanically shopcd such thut the reflected energy is concentrated (focused). . The facets are equipped with alignment adjustments to collectively concentrate the reflected energy from the entire heliostat. The facets are mounted on a structure with azimuth and elevation gimbals to allow aiming the reflected cnergy at inultiple target locations.

Each heliostat gimbal can be driven at angular rates of 5.6 millintalians/s for the l'ast or slew mude and 0.3 milliradians/s.for the slow or sun-tracking mode. Gimbal position sensors provide $2^{13}(8192)$ discrete, angular, switch pusition increments $\left(7.7 \times 10^{-4}\right.$ radians) to which the gimbal can be directeil while tracking. During slew only $2^{10}(1024)$ increments $\left(6 \times 10^{-3}\right.$ radians) are used by the control system.

The facility master control system (MCS) computer provides solar time and position instructions to other hellostat array control (HAC) computers. The HAC computes heliostat required gimbal positions. Control commands are transmitted over signal cables to the heliostats. The control system is assembled in a modular manner with up to 32 heliostats on a signal cable, four signal lines on a computer, and four computers for the total field control. 
The heliostats are stored with the mirror surface facing the ground when not in use. When the beams of energy are moved above the horizon, they will be controlled to concentrate the beams along specific paths. These paths will terminate at a point called the line top (LT) near the experiment. The heliostats can be moved in groups or individually to other off-target hold points called standby points or to the specific target points. "When the heliostats are returned to stowage, they retrack the path.

One of every 10 heliostats is equipped with a detector to determine if the sun is obstructed by a cloud. Tests sensitive to rapid applications of thermal power such as would likely follow passage of a cloud will be protected by moving the group of heliostats off the target when the sun is interrupted. When the sun is again detected the heliostats will be returned to the target in a controlled manner.

B. Focus and Alignment Subsystem (FASS)

Every heliostat and every facet upon the heliostat must be properly oriented to effectively collect energy. The FASS consists of a laser collimator ( $\mathrm{L} / \mathrm{C}$ ), control and monitoring equipment at the heliostat, and a display target.

The beam from the $\mathrm{L} / \mathrm{C}$ is approximately the size of the facet. The control system is used to align the laser reflection from the center facet so that it is displayed on the target. The facet is then focused mechanically to give minimum image size at the display target. The heliostat positional encoders are recorded when the $\mathrm{L} / \mathrm{C}$ reflection from the center facet is centered on the

- target. For the rest of the facets, the heliostat is oriented by the computer to form the proper relative angle between facets and the facets are individually aligned to. reflect the laser beam to the target center.

\section{Working Receiver}

A nominal $1 \mathrm{MW}_{\mathrm{t}}$ working receiver is part of the STTF and is available for diagnostic and experimental work at the facility. The working receiver is built as two major assembles and interconnecting piping. One assembly is an equipment skid with a heat exchanger, pump, and expansion tank permanently mounted at the 45.7 meter (150 ft) level in the tower. The second assembly (Figure 5) is an array of heat absorbing panels mounted on a mobile base. The interconnecting piping between the two assemblies is the two pair of $15.2 \mathrm{~cm}(6 \mathrm{in}$. $)$ water/glycol lines listed under tower utilities. One pair of these lines provides a loop through the STTF heat rejection system (HRS) dry cooling towers and the equipment skid heat exchanger. The second pair of lines provides a loop through the heat absorbing panels and the equipment skid heat exchanger. This second pair of lines has 6 -inch hose connectors at tower top and all test bays so the heat-absorbing loop can. be "plugged in" at any of these locations. 


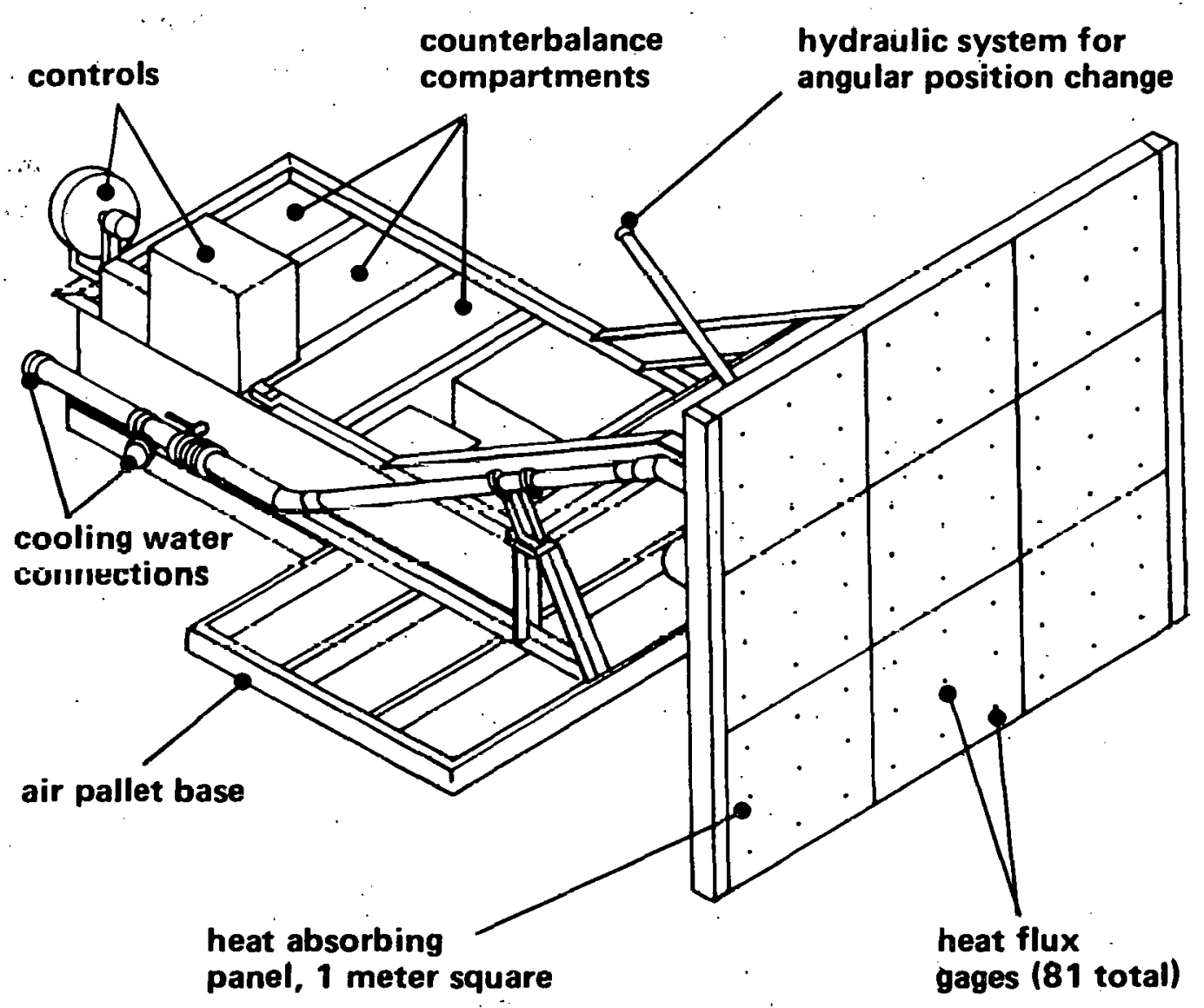

Figure 5. $1 \mathrm{MW}$ Working Receiver.

'The heat exchanger is rated nominally at, $1 \mathrm{MW}_{\mathrm{t}}$ and morc specifically us $50 \cdot 1 /$ sec ( $800 \mathrm{gal} /$ min) and $72 \mathrm{kPa}(10.5 \mathrm{psi})$ pressure drop across the hot side and $251 / \mathrm{sec}(400 \mathrm{gal} / \mathrm{min})$ and 21 $\mathrm{kPa}(3.0 \mathrm{psi})$ pressure drop across the cold side with a $33 \%$ glycol/water mixture on both sides. The pump is in the hot side loop and rated at $501 / \mathrm{sec}(800 \mathrm{gal} / \mathrm{min})$ at $240 \mathrm{kPa}$ (35 psi). The highest temperature is the $67^{\circ} \mathrm{C}\left(152^{\circ} \mathrm{F}\right)$ fluid from the heat absorbirig panels.

The heat absorbing panels are arranged in a 3 by 3 planar array. Each panel is nominally one meter square. The panel array hydraulically pivots about a horizontal axis near its center point. The panel artay surface normal will range from horizontal to $60^{\circ}$ below horizontal. The panel array is cantilevered out from a mobile base that rides on an air-blower/air-caster system.

Each heat absorbing panel is cooled by a 33 percent ethylene glycol/water solution. The panels operate at a minimum of $240 \mathrm{kPa}$ (35 psia) and the fluid solution is lept well below the $136^{\circ} \mathrm{C}$ $\left(277^{\circ} \mathrm{F}\right)$ boiling temperature. The panels are an all copper welded fabrication designed to absorb $0.5 \mathrm{MW}_{\mathrm{t}}$ of energy uniformly distributed across the panel. All panels cannot absorb this quantity of energy simultaneously without overloading the $1 \mathrm{MW}$ heat exchanger. 
Each panel is instrumented with a turbine flowmeter in the coolant inlet line, thermocouples in the coolant inlet and outlet lines, and nine circular foil heat flux gages with thermocouples built into its base. The panel array coolant circuit is instrumented with a total flow turbine flowmeter and thermocouples in both the inlet and outlet lines.

Each panel is equipped with a flow control valve and a calibration valve in the coolant outlet line. The calibration valve diverts panel flow to a weigh tank or similar device for flowmeter calibration.

D. Real Time Aperture Flux System

This system allows actual measurement of the flux density in the aperture plane. Circular foil heat flux gages and high intensity photovoltaic cells are used to obtain high accuracy over the entire spectral range.

The system uses 0 to $3400 \mathrm{~W} / \mathrm{m}^{2}\left(0-300 \mathrm{Btu} / \mathrm{ft}^{2}-\mathrm{s}\right)$ heat flux gages (calorimeter type) that exhibit a linear response over the entire spectral and thermal range. These gages are linear from approximately $0.25 \mu \mathrm{m}$ to $30 . \mu \mathrm{m}$, and the response time is within 100 milliseconds. .

The photovoltaic cells are used in conjunction with the gages because of their fast response time. The gages can be used for a baseline and then the cells can be used for a fast sweep of the aperture. The cells were designed for:

Dynamic Range 40-4000 suns

Deviation of Short-Circuit Current Response from Linearity vs Concentration--2\%

or less over full-dynamic range vs Temperature--5\% or less for $50^{\circ} \mathrm{C}$ change

Angular Acceptance

$\pm 60^{\circ}$ with less than $10 \%$ deviation from cosine law

Both detectors are mounted together in a fixed array, $7.6 \mathrm{~cm}$ to $10.2 \mathrm{~cm}(3$ to 4 in.), spacings on a water cooled bar which will be adapted to scan the receiver or experiment aperture. The data will be collected and analyzed by a dedicated computer system and will be used to fine-tune the heliostat beam and provide flux data for the experimenter.

\section{E. Computerized Heliostat Beam Model}

HELIOS, Sandia Laboratories' ray trace program, is an analytical tool of many capabilities. The heliostat field may be modeled to allow the user to study many different operating situations. HELIOS will calculate the solar radiation intensity reflected from the heliostats to any desired location. This allows calculations for many operational and safety situations. HELIOS can be used to calculate the flux density on a given surface (receiver or other experiment) or to determine 
pointing strategies to give a desired flux distribution. Following is an outline of some of the capabilities of HELIOS that will be used to assist in tailoring the beam to the needs of the experimenter:

1. Model receiver and other experiments located on or off the tower.

2. Operate with any heliostat or group of heliostats.

3. Plü and print output options.

4. Model shadowing and blocking.

5. Choice of six sun shape options including the ability to model the measured sun shape.

6. Read in insolation or calculate it.

7. Specify sun error cone.

0. Tle larget location and the aim point are independent.

9. Focus heliostats on any location at any time of the year.

10. Vary target size and shape.
a. rectangular shape
b. cylindrical shape (inside or outside)
c. spherical shape (inside or outside)

11. Account for field slope; therefore, different geographical locations can be analyzed.

12. Choose different facet geometric representations and sizes available (ti nptions).
a. parabolic shape
b. tlat facet shape
c. facet shaped by uniform pressure applied to a pull point and ring support
d. facet shaped by uniform pressure on a pull ring and ring support
e. continuousiy focusing facet shape
f. . spherical shape

13. Study different operating and safety situations.
a. total power loss (lock problem)
b. emergency stow (elevation slew only)

14. Mndel different eyotcm crrors.
a. facet surface errors
b. focus errors
c. alignment errors 

d. aiming errors
e. tracking errors

15. Model unique problems.
a. user-supplied subroutine to describe any target shape if rectangular, spherical and cylindrical options are not good enough
b. actual facet surface normals can be entered into the program if one of the 6 facet options is inadequate or inaccurate

Examples of HELIOS calculations are given in Tables II and III. The calculations are for noon on day 80 (vernal equinox). The insolation was $0.1 \mathrm{~W} / \mathrm{cm}^{2}$. A measured sun shape (circumsolar telescope) and a spherical facet shape were used. The results are presented as the sum of the power $\left(\mathrm{W} / \mathrm{cm}^{\ddot{2}}\right.$ ) from all heliostats intercepted by a 11 by 11 node rectangular target mesh. The dimensions are in meters. The coordinates given for points $1,11,111$, and 121 are the $x$, $y, z$ dimensions in meters with the ground level center of the tower being $0,0,0$. The target mesh was facing north. Similar results are available for each contributing facet and each total heliostat. Table II is for the Zone A (78) heliostats aimed at a target in the $140^{\prime}$ test bay. Table III is for Zone A and B (222) heliostats aimed at a target on.top of the tower (above $200^{\prime}$ ). Similar results can be generated for any target location, variable target sizes and shapes, and heliostat locations.

\section{F. STTF Tower}

\section{General Description}

The STTF receiver tower rises $61 \mathrm{~m}(200 \mathrm{ft})$ above ground level and extends $15.2 \mathrm{~m}(50 \mathrm{ft})$ below ground. The nominal tower cross section is circular with rectangular projections on the north and south sides as shown in Figure 6.

The tower cross section begins to taper at the $56.4 \mathrm{~m}$ (185. ft) level and is smallest at the $61 \mathrm{~m}(200 \mathrm{ft})$ level as shown in Figure 7. The taper minimizes flux blockage at the $61 \mathrm{~m}(200 \mathrm{ft})$ level. At ground level the tower cross section is basically a circle as shown in Figure 8. The extra area, which is one story high, is used to house mechanical and electrical equipment.

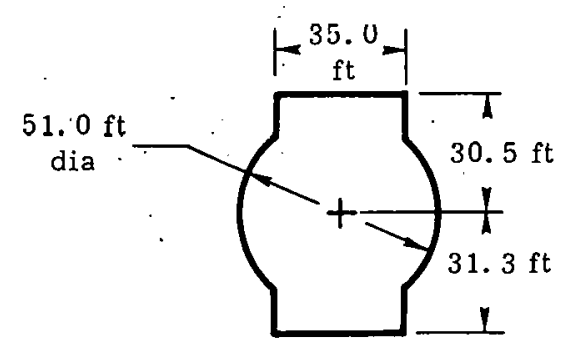

Figure 6. Nominal Tower Cross Section

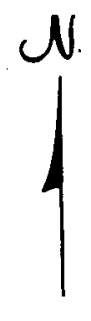

. Figure 7. Nominal Tower Cross Section

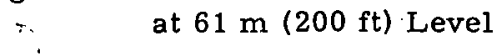


73 Heliostats, Zone A, Aimed at Target in 140-Fcot Test Bay

POWER FROM HELIOSTA'S ONTC TERGET SURFACE FOR THE FIRST DAY AND FIRST TIME OF DAY PROCESSED (HATTICME*2)

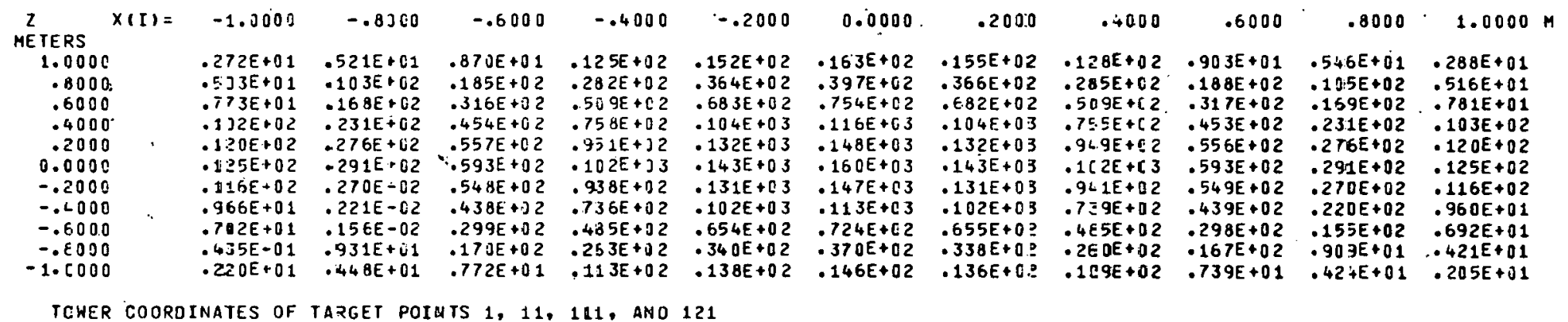

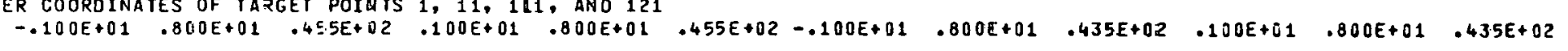

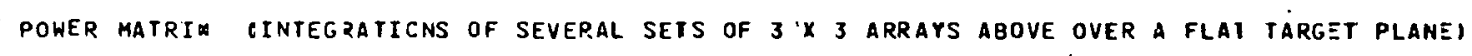

$\begin{array}{ll}.1770-E+05 & .4658 E E+05 \\ .38935 E+05 & .11923 E+06 \\ .49103 E+05 & .1586 E+06 \\ .37405 E+05 & .11602 E+06 \\ .16083 E+05 & .43611 E+05\end{array}$

TOTAL PJHER ON -ARGET SURFACE IS

CHECK OF POHER MATRIX

$\begin{array}{ll}.17594 E+05 & .46584 E+05 \\ .38342 E+05 & .11922 E+06 \\ .4913 E E+05 & .15866 E+06 \\ .37411 E+05 & .11602 E+06 \\ .16070 E+05 & .43606 E+05\end{array}$

TOTAL POWEP ON TARGET SUPFACE IS
$.64934 E+05$

- $17679 E+06$

$.17321 E+C 6$

$.60873 E+05$
$.46942 E+85$
$.11889 E+06$

$.15867 . E+06$

$.11630 E+06$
$.43189 E+05$

$.20025 E+07$ HATTS.

\section{E-05}

$\therefore 2942 E+05$

- $49092 E 105$

$.37337 E+05$
$.15740 E+05$

EFFECTIVE AREA INTERCEPTING SUN $=.2814$ I +04 SQUARE METERS

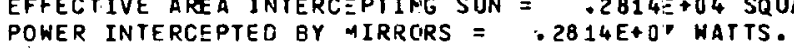

ERROR ESTIMATE FOR POWER MATREX

$\begin{array}{lll}.15487 E+03 & .25540 E+02 & .46477 E+03 \\ .79586 E+02 & .13112 E+02 & .18237 E+03 \\ .31848 E+03 & .65702 E+01 & .94673 E+03 \\ .70751 E+02 & .15495 E+02 & .19897 E+03 \\ .15610 E+03 & .51490 E+02 & .46597 E+03\end{array}$

$.64973 E+05 \quad .46938 E+05$ $.17677 E+06 \quad .11889 E+06$ $.24021 E+06 \quad .15867 E+06$ $\begin{array}{ll}.17319 E+06 & .11636 E+G 6 \\ .50912 E+05 & .43186 E+05\end{array}$

$-17397 E+05$

$.43119 E+05$

$.3+343 E+05$

.15.27E*05

TIME FDR G IS $\begin{array}{r}\text { ESTIMATEJ ERROR } \\ 462.660000\end{array}$ 


\section{TABLE III}

222 Heliostats, Zone A, Aimed at Tower Top Receiver

POWER FROM HELIOSTATS ONTO TARGET SURFACE FOR THE FIRST DAY AND FIRST TIME OF OAY PROCESSED (HATT/CM**2)

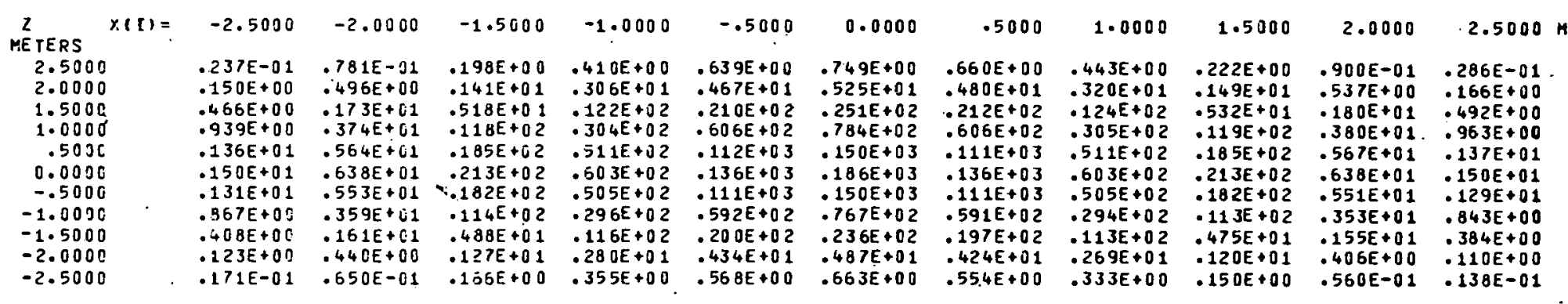

TONER COOROINATES OF TARGET POIHTS $1,11,111$, AND 121

$\begin{array}{lllllllllllll}-.25 J E+[1 & .45 J E+J 1 & .683 E+22 & .250 E+01 & .450 E+01 & .683 E+02 & -.25 E E+01 & .450 E+01 & .633 E+02 & .250 E+01 & .450 E+01 & .633 E+02\end{array}$

POHER MATRIX IINTEgRatIONS OF SEVERAL SETS OF $3 \times 3$ arRays above OVER a flat target plane)

$\begin{array}{lllll}.75835 E+04 & .41851 E+05 & .74708 E+05 & .43110 E+05 & .80149 E+04 \\ .46021 E+05 & .32914 E+06 & .75164 E+06 & .33022 E+06 & .46572 E+05 \\ .77043 E+05 & .62753 E+06 & .15835 E+07 & .62751 E+06 & .77019 E+05 \\ .44395 E+05 & .32162 E+06 & .73743 E+06 & .32033 E+06 & .43827 E+05 \\ .58846 E+04 & .39063 E+05 & .69477 E+05 & .37949 E+05 & .65158 E+04\end{array}$

TOTAL POHER ON TARGET SURFACE IS $.62990 E+07$ WATIS.

CHECK OF POHER MATPIX

$\begin{array}{llll}.75064 E+04 & .41719 E+05 & .75136 E+05 & .42976 E+05 \\ .75999 E+05 & .32869 E+06 & .75260 E+06 & .32976 E+06 \\ .75251 E+05 & .62874 E+06 & .15805 E+07 & .62871 E+06 \\ .74370 E+05 & .32114 E+06 & .73846 E+06 & .31985 E+06 \\ .668380+04 & .33942 E+05 & .69852 E+05 & .37830 E+05\end{array}$

$.79377 E+04$

$.04599 E+05$

$15805 E+07$

$0.098525+05$

$.37830 \mathrm{E}+05$

TOTAL POWER ON TARGET SURFAGE IS

$.62988 E+07$ HATTS.

EFFECTIVE AREA INTERGEPTING SIJN $=.7977 E+04$ SQUARE METERS

POHER INTERCEPTEO BY MIRRORS $=.7977 E+07$ WATTS.

ERROR ESTIMATE FOR POHER MATREX.

$\begin{array}{lll}.92513 E+03 & .15850 E+04 & .51358 E+04 \\ .25972 E+03 & .56914 E+04 & .11591 E+05 \\ .25013 E+04 & .14418 E+05 & .36574 E+05 \\ .30443 E+03 & .57590 E+04 & .12336 E+05 \\ .91913 E+03 & .14466 E+04 & .44982 E+04\end{array}$

$.16068 E+04$ $.55397 E+04$

$.14418 E+05$

$.57156 E+04$

$.14254 \mathrm{E}+04$

$.46551 E+05$

$.77227 E+05$

$.64399 E+04$ 

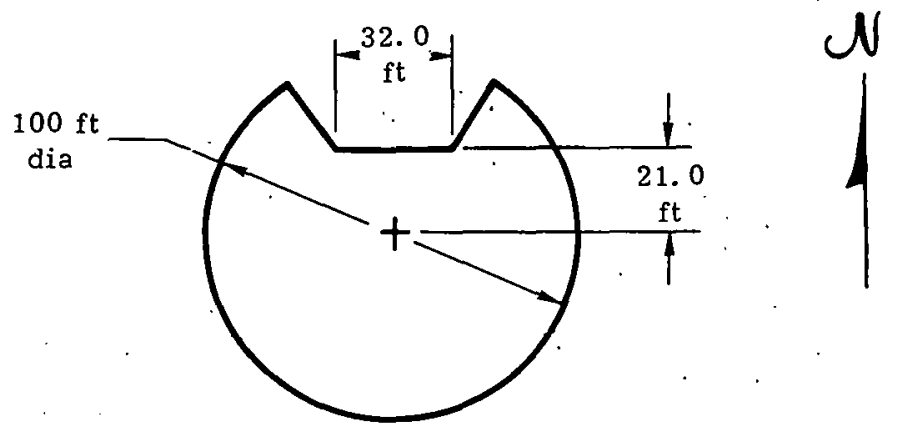

Figure 8. Nominal Tower Cross Section at Ground L̇evel

The south projection of the nominal tower cross, section hnuses stairs and elevatorg. Tho north projection provides extra area for experiment losations. Platforms are located ingido the tower at $6.1 \mathrm{~m}(20 \mathrm{ft})$ intervals both above and below ground level.

Test bays for experiments are located on platforms at the $36.6 \mathrm{~m} 42.7 \mathrm{~m}$, and $48.8 \mathrm{~m}(120$, 140, and $160 \mathrm{ft}$ ) levels as shown in Figure 9. Experiments can also be conducted at the top of the tower. The test bays at the $36.6 \mathrm{~m}$ and $42.7 \mathrm{~m} \mathrm{(120} \mathrm{and} 140 \mathrm{ft})$ levels are in rooms approximately $9.8 \mathrm{~m}$ (32 ft) wide (east-west) by $4.6 \mathrm{~m}$ (15 ft) deep (north-south) with a $5.2 \mathrm{~m}$ (17 ft) ceiling and are equipped with $6.7 \mathrm{~m}(22 \mathrm{ft})$ wide by $4.6 \mathrm{~m}(15 \mathrm{ft})$ high roll-up steel doors on the north walls. These rooms have no south wall as they are open to the tower interior. The test bay at the $48.8 \mathrm{~m}$ $(160 \mathrm{ft}$ ) level is on an exposed platform and is approximately $10.7 \mathrm{~m}$ (35 ft) wide (east-west) and $3.0 \mathrm{~m}(10 \mathrm{ft})$ deep (north-south). This test bay has no overhead structure and access is provided

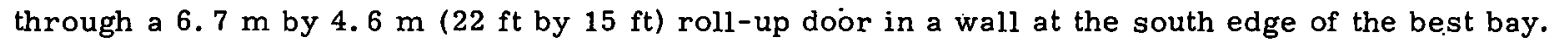

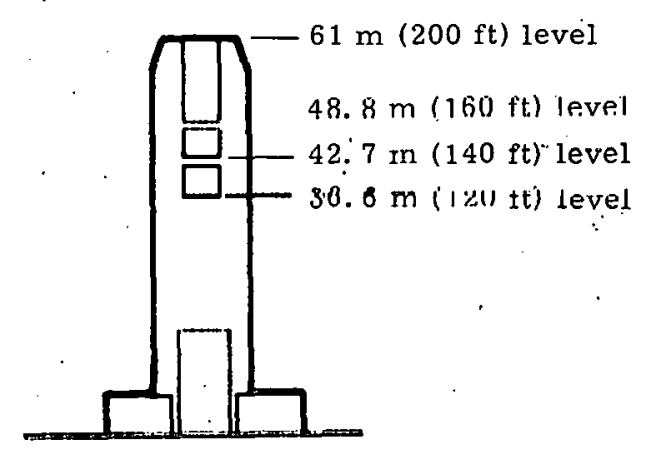

Figure 9. North Tower Elevation Showing Tcst Bays 


\section{Elevators and Hoists}

Hardware can be transported to the test bays or tower top in two ways. Hardware up to $4536 \mathrm{~kg}(10,000$ pounds) can be hoisted up the outside of the tower on the north side. Heavier hardware can use the elevating module which runs up the tower interior.

The $76.2 \mathrm{~m}(250 \mathrm{ft})$ tower interior has $9.1 \mathrm{~m}$ by $7.6 \mathrm{~m}$ (30 ft by $25 \mathrm{ft}$ ) rectangular hoistway with an elevating module. The elevating module is nominally $9.1 \mathrm{~m}(30 \mathrm{ft})$ wide by $7.6 \mathrm{~m}(25 \mathrm{ft})$ deep by $13.1 \mathrm{~m}$ ( $43 \mathrm{ft}$ ) high. The elevating module roof can be positioned anywhere between ground level and the $61 \mathrm{~m}(200 \mathrm{ft})$ level. Ground level access to the elevating module roof is provided by a $9.8 \mathrm{~m}$ (32 ft) wide by 16.8 (55 ft) high sliding steel door on the north side of the tower. A $9.1 \mathrm{~m}$ $(30 \mathrm{ft})$ by $7.6 \mathrm{~m}(25 \mathrm{ft})$ trap door at the top of the tower folds into the tower and provides a tower top opening for any hardware riding the elevating module roof. The same trap door provides a work platform at the $61 \mathrm{~m}(200 \mathrm{ft})$ level if the elevating module is at another location. The elevating module will lift experiments weighing up to $90,700 \mathrm{~kg}(200,000$ pounds $)$.

The elevating module is an enclosed three-story building in itself. Each story is laid out as a single room. The top room contains instrumentation path panels, the middle room contains the STTF data acquisition system and the lower room is a light machine shop. The floors of the middle and lower rooms are 20 feet apart to match the internal tower platform interval.

The elevating module can be locked into position whenever the roof is located at any of the test levels or at ground level. With the elevating module locked in position, the four lift ropes detach from the elevating module and are used individually or in any combination for auxiliary hoisting. The working lift load of each wire rope is $54,400 \mathrm{~kg}(120,000$ pounds).

A $9.1 \mathrm{~m}$ by $7.6 \mathrm{~m}$ ( $30 \mathrm{ft}$ by $25 . \mathrm{ft}$ ) platform stores on the floor of the tower hoistway at the $-15.2 \mathrm{~m}(-50 \mathrm{ft})$ level. The lift ropes are used to position this working-platform flush with any tower platform below the elevating module.

The tower interior is also serviced by two $4536 \mathrm{~kg}(10,000$ pound $)$ jib cranes mounted at the $24.4 \mathrm{~m}$ ( $80 \mathrm{ft}$ ) level. These cranes primarily support light assembly work on the elevating module roof with the roof at ground level.

The test bays at. the $36.6 \mathrm{~m}$ and $42.7 \mathrm{~m} \mathrm{(120} \mathrm{and} 140 \mathrm{ft})$ levels are serviced by $4536 \mathrm{~kg}$ (10,000 pound) hand-geared bridge cranes. The bottom of the bridge beam is approximately $4.4 \mathrm{~m}$ (14. $5 \mathrm{ft}$ ) above floor. 
The roof of the elevating module structurally interfaces with tower-lop experiments and is structural steel framing covered with a one-half-inch thick steel plate. Large tower-top experiments must have support features engineered to match up with this roof structure.

\section{Thermal Protection}

All tower thermal protection is passive. The north face of the tower above the $33,5 \mathrm{~m}$ $(110 \mathrm{ft})$ level is built with an easily replaceable sacrificial layer of concretc. Depending on location, this is either a $5.1 \mathrm{~cm}$ ( 2 in.) thick layer of concrete-like material sprayed on top of the basic slip formed tower shell or $7.6 \mathrm{~cm}$ (3 in.) thick preformed concrete panels which stand off from the tower shell.

The STTF. also provides a supply of thermal protection panels to he used as radiation shielus. The primary purpose of these panels is to shield the tower interior and experimental hardware from goler flux spillage. The roll-up stepl dopre on the various lest bays do not qualify as thermal protection.

\section{Utilities}

The tower is built with a mechanical chase running up the east side of the tower and an electrical chase running up the west side of the tower. The mechanical chase contains the following lines:
4 ea. 6-inch water/glycol
1 ea. 1-1/2-inch water/glycol supply
1 ea. 1-1/2-inch water/glycol return
1 ea. $3 / 4-i n c h$ compreascd. nitivgen
1 ea. 3/4-inch control compressed air
1 ea. 1-1/2-inch compressed air (not control quality)
1 ea. 4-inch draín
1 ea. 2-inch receiver feedwater suppiy
1 ea. 1-inch receiver blowdown
1 คа: 1/2-inch revuivos bampliry
1 ea. 3-inch high pressure steam.
1 ea: 2-inch cold water
1 ea. 1/2-inch chemical feed

All these lines are terminated at the tower top and at each of the lower test bays. Sewer and fire protection lines also run in the mechanical chase. Room exists in the mechanical chase for arditiunal lines.

\footnotetext{
These lines are standard U.S. sizes - metric equivalents are not appropriate.
} 
The electrical chase contains $115 \mathrm{VAC}$ single phase, $208 \mathrm{VAC}$ three phase and $480 \mathrm{VAC}$ three phase power. The 115 and $208 \mathrm{VAC}$ is distributed throughout the tower. The $480 \mathrm{VAC}$ is available only at the tower top and test bays. Power lines for tower equipment and data acquisition system lines also run in the electrical chase. Room exists in the electrical chase for a large number of additional conduits or other lines as required by future needs.

Heat Rejection System (HRS)

The primary functions of the tower HRS are to supply preconditioned feedwater and cooling fluid to receiver experiments and to dissipate the energy collected by receiver experiments. The HRS, shown schematically in Figure 10, can supply boiler quality feedwater at a maximum rate 3. $161 / \mathrm{s}(50 \mathrm{gpm})$ and a maximum temperature and pressure of $204^{\circ} \mathrm{C}\left(400^{\circ} \mathrm{F}\right)$ and $15.5 \mathrm{MPa}$ (2250 psi), respectively. The HRS can also supply $25.21 / \mathrm{s}(400 \mathrm{gpm})$ of a 33 percent ethylene glycol/water solution to experiment locations. The HRS can accommodate $9000 \mathrm{~kg}(20,000 \mathrm{pounds})$ per hour of $518^{\circ} \mathrm{C}\left(965^{\circ} \mathrm{F}\right)$, 13. $8 \mathrm{MPa}(2000 \mathrm{psi})$ steam.

The feedwater system starts at the STTF potable water supply. Water is passed through cation, anion, and mixed demineralizer beds and stored in a 37, 8501 (10,000 gallon) tank. The water is pumped from the tank into a low pressure, 1.6 MPa (233 psi), spray water loop that contains a deaerator desuperheater and heat exchanger. Hydrazine is added at this spray water loop. Feedwater is then pumped from the spray water loop into high pressure pipe running up the tower to the receiver experiment. Acidity control chemicals are added in this high pressure pipe.

The feedwater returns down the tower in a high pressure steam line, passes through a pressure reducing valve and into the deaerator desuperheater vessel, thus completing the cycle. The feedwater returns from the receiver experiment along the same path whether it is water or steam.

A.closed-loop dry cooling tower system dissipates energy returned in the feedwater/steam. The cooling tower loop uses a 33 percent ethylene glycol-water solution for coolant and passes the coolant through the cold side of the heat exchanger in the feedwater spray water loop. . Coolant at $94.6 \mathrm{l} / \mathrm{s}(1500 \mathrm{gpm})$ is supplied to the heat exchanger. A second $25.2 \mathrm{l} / \mathrm{s}$ ( $400 \mathrm{gpm}$ ) pump taps coolant from the cooling tower loop and pumps it up the tower to the working receiver equipment skid heat exchanger and also provides coolant at each test level.

A receiver blowdown line is routed down the tower and into an underground blowdown holding chamber. Five water sample points built into the HRS feed a water sample table in the tower base. Two chemical feed mixing tanks and metering pumps are provided for the feedwater $\mathrm{pH}$ and $\mathrm{O}_{2}$ control chemicals. A glycol-water mixing tank is provided for glycol-water makeup in the dry cooling tower loop. A 1514 l (400 gallon) industrial waste water collection tank is provided for drain system waste. 


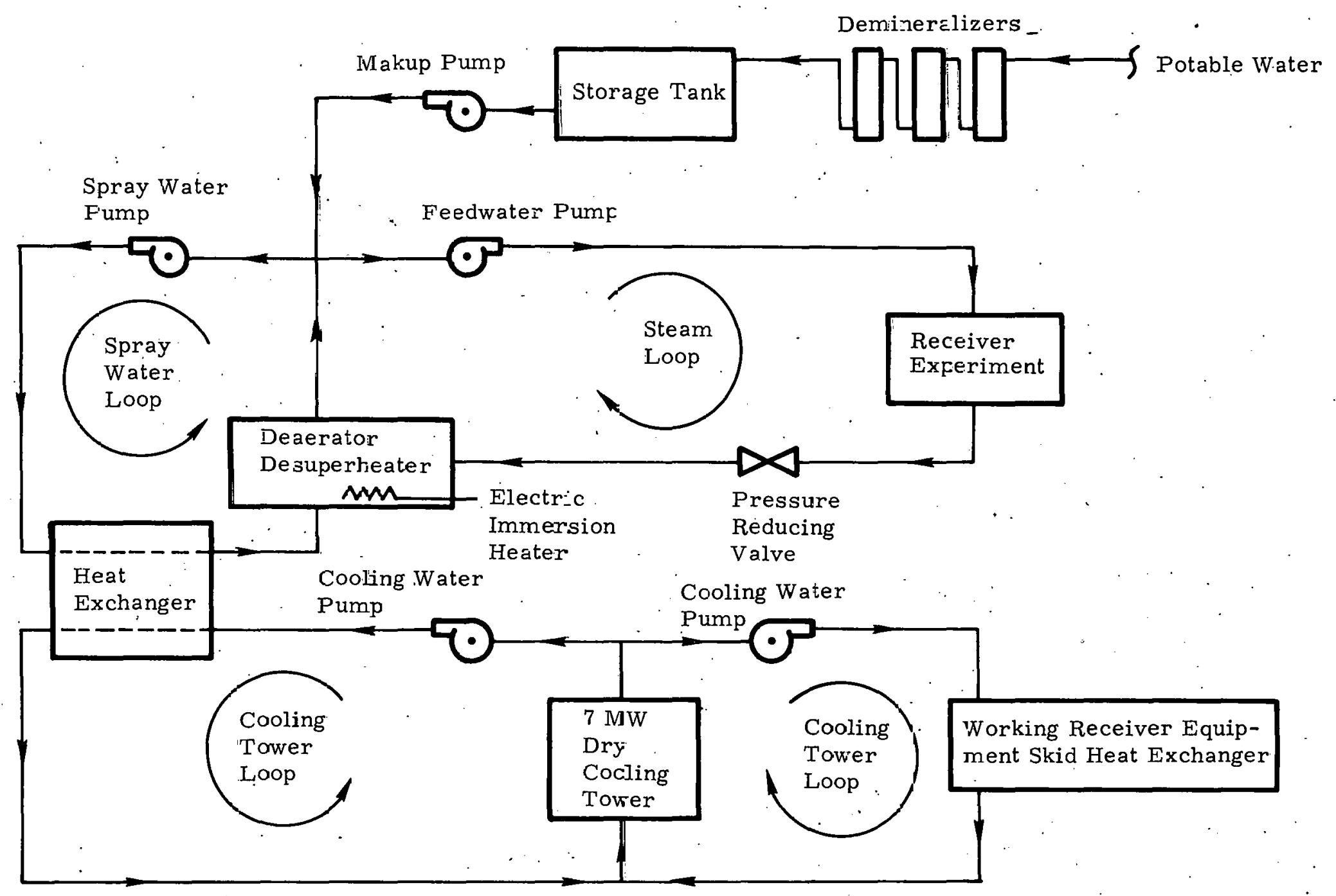

Figure 10. Simplified Schematic, Heat Rejection System 


\section{G. Data Recording and Control}

The STTF uses a multiple-computer distributed control system to control the heliostats, - heat rejection, water treatment, and other facility functions. An integral part of this computerbased Master Control System (MCS) is a data acquisition capability, since some of the data are used for control. The Master Control System uses three Hewlett Packard (HP) 9611A minicomputer systems and two mobile measurements and'control "front end" HP 9611R subsystems. One minicomputer is used for the Meteorological Data System (MDS). One is used as the MCS central computer and is used to transmit data to the MCS central computer.

The MCS central minicomputer is located in the Remote Terminal and Data Reduction room of the Control and Administration Building. All experiment and facility data are recorded on the central system's disc, and data are accessed, analyzed, and displayed at the central computer. This computer is also the operators' control points to the MCS.

The third MCS minicomputer is located in Room 2 of the receiver tower elevating module. This minicomputer has no local data recording capability, but instead transmits the data to the MCS central where they are then recorded on disc. The tower system is thus designed to be operated as a satellite of MCS central, either remotely from the central during tests or locally for setup. The MCS tower satellite is the main data acquisition node and is interfaced to an industrial-quality HP2313B analog-to-digital (A/D) converter subsystem; complete with modular, expandable analog multiplexers, programmable pacer (sample rate clock), sample and hold amplifier, and 12 bit converter. The A/D input subsystem may be programmed in random address (multiplexer channels in any order), sequential address (consecutively numbered channels) or single address (one channel) modes. An industrial-quality HP6940 Digital Input-Output (DIO) subsystem is also interfaced to the MCS tower satellite for digital input. digital output, and analog output. The 1.2-bit DIO subsystem is used mostly for control of the central receiver experiment.

The two mobile measurement and control A/D and DIO systems are interfaced to either the MCS central or tower satellite minicomputer over the same double twisted-pair cable connecting the computers. One of these mobile systems will be used at the base of the receiver tower for the facility controls and data. Both these systems and the tower satellite computer are hardware compatible, with each A/D expander holding up to twelve 16-channel multiplexers, for a maximum of 480 channels per system.

The same flexible modularity is used for the signal conditioning as for the digitized system. Each 36-channel thermocouple reference junction chassis allows plug -in of the transducer, easy patching of the voltage output to a particular A/D channel and complete shielding of each channel. Both type $\mathrm{K}$ (chromel-alumel) and type $\mathrm{T}$ (copper-constantan) thermocouples will be referenced, with 250 channels of $\mathrm{K}$ and 100 channels of $\mathrm{T}$ with the mobile "front ends." Strain gages will have 10 channels of 1,2 , or 4 arm bridge completion circuits and a separate $0-15 \mathrm{~V}$ power supply in each chassis. The elevating module will accommodate up to 150 channels of strain gages, and 150 more channels will presently be with the mobile systems. 
The individual capabilities of the computer digitizing systems and the signal conditioning as specified by the manufacturers are as follows:

1. Analog Input to Computer, Hewlett Packard 2313B.

a. Basic Sample and Hold, Analog-Digital Converter.

Resolution, 12 bits, including sign, LSB $=5 \mathrm{mV}$

Full Scale Input, $+10.235 \mathrm{~V}$ to $-10.24 \mathrm{~V}$.

b. Solid State Low Lével Analog Multiplexers, HP91111A.

Each plug-in card has 16 differential channels.

Full Scalle Inputs, programmable for $\pm 10 \mathrm{mV}$ to $\pm 800 \mathrm{mV}$

in binary sequence.

Overall Accuracy (worst case), $\pm 0.38 \%$

$+1 / 2$ I.SR at 50 sampleg/3econd.

Sample Rates up to 8,000 channels/second with local

computer, nominally used to 1000 channels/second for most

tests; up to 1000 chamnels/second"for mobile "front end"

subsystems.

Source Resistance, less than $100 \mathrm{ohms}$ for rated accuracy,

$1 \mathrm{k}$ ohm maximum.

Common Mode Rejection, greater than $100 \mathrm{~dB}$ up to $1 \mathrm{k}$ ohms unbalance.

Input Voltage (signal plus common mode), cannot exceed $10 \mathrm{~V}$ peak between inputs or between any input and ground. Signals must be referenced to system grnind.

c. High Level Analog Multiplexers, HP91110A.

Each plug-in card has 16 differential channels.

Full scale inputs, $+10.235 \mathrm{~V}$ to $-10.24 \mathrm{~V}$.

Overall accuracy (worst case), $\pm 0.09 \%+1 / 2 \mathrm{I}$.SB

Sample rates up to 45,000 channels/second with local computer, nominally used to 2000 channels/second for most tests; up to 1000 channels/second with mobile "Irunt enas." Source resistanre, less than 1 k olmi Lidaxlenum.

Common Mode Rejection, greater than $80 \mathrm{~dB}$ up to $1 \mathrm{k} \mathrm{ohm}$ maximum unbalance.

Input yoltage (signal plus common mode), cannot exceed $15 \mathrm{~V}$ peak any input to gruund. 
d. Solid State Analog Current Multiplexers, HP91224A.

Each plug-in card is essentially the low level voltage multiplexer, HP9 1111A, with a $4 \mathrm{ohm}$, fused shunt per ISA Standard S50. 1. Full scale inputs, $2.5 \mathrm{~mA}$ to $200 \mathrm{~mA}$. Overall accuracy (worst case), $\pm 0.58 \%$. $\pm 1 / 2 \mathrm{LSB}$ at 50 samples/second.

Other specifications similar to voltage multiplexer.

2. Analog Output from Computer, HP91206/91207A (Cointrol signals)

a. Each plug-in card is a single voltage (91206A) or current (91207A) Digital-to-Analog (D/A) converter.

Voltage output, +10.235 to $-10.24 \mathrm{~V}$ at $0-5 \mathrm{~mA}$, short protected, $5 \mathrm{mV}$ LSB.

Current output, 0 to $20.475 \mathrm{~mA}$ at $0-10.5 \mathrm{~V}$ compliance.

3. Digital Input to Computer

a. Direct Input with Handshake, HP91202A.

Inputs, 12 bits, TTL-compatible, ground-true.

Handshake signals, TTL-compatible:

Gate low (ground) slate indicates computer ready for

data from external source.

Flag high to low transition indicates external device busy; return to high state indicates inputs are available.

b. Event Sense Inter rupt, HP91205A.

Twelve data lines are compared to reference word, computer interrupted if lines are equal/unequal to references. Used to monitori contacts. Oper, $>1 \mathrm{~m}$ uhm to ground, Closed, < 100 ohms to ground, standard dry contact configuration. Can be used with modules to sense presence or absence of either.

$$
\begin{aligned}
& 95-130 \mathrm{VAC} \\
& 10-55 \mathrm{VAC}
\end{aligned}
$$

4. Digital Output from Computer

a. Mercury-Wetted Relay Output, HP91204-010 (Control Signals)

Twelve normally-open contact pairs.

Operating Times, 3.5 milliseconds

Ratings, $100 \mathrm{~V}$ AC or DC, 1.0 A switching, $20 \mathrm{~W}$, maximum. 
Solid State Relay Output, HP91223A (Control Signals).

Twelve-channel normally-open circuits to switch either

$\dot{A C}$ or $D C$ solid state relays.

AC Relays, 20-250 VAC, $10 \mathrm{~mA}-2 \mathrm{~A}$.

DC Relays, 4-55 VDC, $2 A$ (unidirectional).

5. Thermocouple Reference Junctions.

a. Reference junction temperature: $150^{\circ} \mathrm{F}$.

b. Thermocouple type: Type K (chromel-alumel) or

Type $\mathrm{T}$ (copper-constantan).

‥ Number of channels per chassis: 36 ,

d. Input connections: 3 pin thermocouple jask (frnnt surfaoe).

e. Output connections: Terminal strips (rear surface).

f. Shields carried through.

6. Strain Gage Signal Conditioners.

a. Input: 1, 2, 4 arm strain gage and strain gage transducers. .

b: Standard $120 \mathrm{ohm}$ strain gages. (Selector switch per channel--local and/or remote).

c. Capacity: 10 channels per chassis.

d. Power: 1 supply per chassis $(0+15 \mathrm{~V})$ : Input $115 \mathrm{Volt} A \mathrm{C}, 40-400 \mathrm{IIz}$.

c. Shield carried through.

f. Coarse balance switch: +4000 micro-strain, 0, -4000 micro-strain.

g. Calibration: Single shunt per channel, local or remote.

h. Noise: Less than 5 volts peak to peak per channel,

i. Input wiring: 3 to 6 wires plus shield.

7. Linear Variable Differential Transformer (LVDT) Signal Conditioners.

a. Input: 4,5 , or 6-1ead LVDT's.

b. Capacity: 10 channels per chassis.

c. Power: 1 supply per chassis, $\pm 15 \mathrm{~V}, 0.1 \%$ regulation $\pm 40 \mathrm{~mA}$ no-load current maximum.

d. Carrier uutput: $3.0 \mathrm{~V}$ RMS, $2.5 \mathrm{kHz}, 1.0 \mathrm{VA}$ maximum load capability.

e. Input impedance: $40 \mathrm{~K}$ ohms or $100 \mathrm{~K}$ ohms depending upon modular card used.

f. Output, full range: $\pm 10 \mathrm{VDC}$ at less than $100 \mathrm{ohms}$. 


\section{H. Meteorological System}

\section{Components}

The meteorological system consists of:

'1. Hewlett Packard 9611A computer.

2. Towner Systems Sensor Package which includes:

Spot wind direction transducer.

Spol wind speed transducer.

Air temperature transducer.

Relative humidity transducer.

Dew Point transducer.

Barometric pressure transducer.

Precipitation transducer.

Digital interface panels and cables.

Tripod mounted portable wind direction and wind speed transducers..

3. Meteorology Research, Inc. (MRI) Integrating Nephelometer, an electro-optical, instrument which continuously monitors the air and provides a readout of atmospheric particle contamination.

4. EG\&G Forward Scatter Visibility Meter, an electro-optical instrument which determines visual range.

5. Eppley Normal Incident Pyrheliometer, an instrument which measures incident solar radiation.

6. Eppley Black and White Pyranometer, an instrument which measures global (total sun and sky) radiation.

7. Lawrence Berkeley Laboratories Circumsolar Telescope, a scanning instrument designed to measure the effects of atmospheric conditions on the direct and circumsolar components of the solar flux. It incorporates the measurement of total hemispherical insolation in the horizontal plane and in a plane normal to the direction of the sun.

The Towner Systems sensor package will be mounted on a 200 -foot $(60 \mathrm{~m})$ Weather-Measure tower as follows:

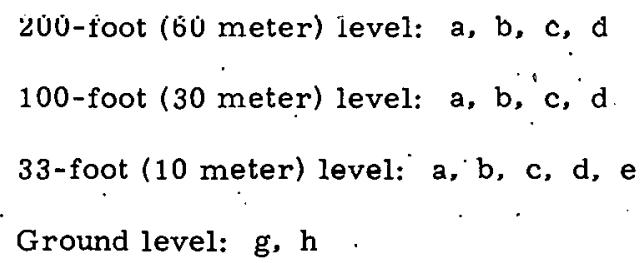


The forward scatter visibility meter and the air intake for the integrating nephelometer will be mounted on the tower. Data from these transducers will be automatically scanned and recorded by the Hewlett Packard computer at selected time intervals.

\section{Capabilities}

The Towner Systems' sensors and other meteorological equipment are oouplcd to the cumputer system by a serial current loop. At selected times, the computer will command readings to be made of specified sensors or equipment. The sensor or equipment outputs will be scanned and the readings recorded on digital magnetic tape, disc, or both. The system is capable of scanning and displaying the data at one second intervals. Readings can also bc transmitted io the Master Control System computer if required during a particular experiment.

Data stored will be in standard ASCII format, readable by any other computer, and will inolude the WWV lucallzed time, the sensnr or equipmont stativin nunber and the readings in engineering units. Computer programs will be prepared to access the recorded data and selectively print out over specified time intervals. Other access programs can be developed as re. quired.

The Towner Systems' transducers are rated as follows:

Wind Direction: $0-359^{\circ}$ azimuth $\pm 2^{\circ}$ above $5 \mathrm{mph}$.

threshold $0.7 \mathrm{mph}$, increments of $1^{\circ}$.

Wind Speed: $0-60$ meters per second $\pm 0.4 \mathrm{~m} / \mathrm{s}$. below $32 \mathrm{~m} / \mathrm{s}$, threshold $0.3 \mathrm{~m} / \mathrm{s}$, increments of $0.1 \mathrm{~m} / \mathrm{s}$.

Alr 'l'emperature: $-45 / 460^{\circ} \mathrm{C} \pm 1 \%$, increments of $1^{\circ} \mathrm{C}$.

Reĺative Humidity: $0-99 \%$ r.h. $\pm 5 \%$ r.h. increments of 1 r.h.

Dew Point: $-33 /+33^{\circ} \mathrm{C} \pm 2 \%$, increments of $1^{\circ} \mathrm{C}$.

Barometric Pressure: 100 millibar range for 5600 feet $\pm 0.3 \mathrm{mb}$. increments of $0.1 \mathrm{mb}$.

Hrecipilation: $0-9.99$ inches $\pm 1 \%$ at 3 inches per hour maximum, increments of 0.01 inch.

The MRI Intëgrating Nephelometer is rated for sensitivity and range as follows:

Scattering Coefficient: 0.1 to $100 \mathrm{E}-4$ per meter:

Local Visual Distance: to 0.3 miles (470 meters).

Mass Concentration: 0 to 3800 micrograms per cubic meter.

Accuracy: $\pm 10 \%$ of scale. 
The EG\&G Forward Scatter Visibility Meter visual range detection is rated from 200 feet (60 meters) to 20,000 (61 meters) $\pm 5 \%$ of forward scatter coefficient.

The Eppley Normal Incident Pyrheliometer has a range of $0-2800$ watts per meter at a rated accuracy of $\pm 0.5 \%$.

The Eppley Black and White pyranometer has a range of $0-1400$ watts per meter ${ }^{2}$ at a rated accuracy of $\pm 1 \%$.

Cosine response is: $\pm 2 \%$ from normalization $0-70^{\circ}$

Zenith angle; $\pm 5 \% 70-80^{\circ}$ Zenith angle.

The Lawrence Berkeley Laboratory circumsolar telescope is rated as follows:

Angular Resolution: 1.5 minutes of arc; from sun center to 2 solar radii.

5.0 minutes of arc; from 2 solar radii to $\pm 3^{\circ}$ from sun center.

Instrument Contribution: Less than $0.5 \%$ with clean entrance window.

Accuracy $= \pm 0.5 \%$ based on Eppley Normal Incident Pyrheliometer.

The LBL circumsolar telescope is normally used to gather sun shape data, but can also be used to monitor reflected and emitted radiation from experiments.

I. Administration and Control Building

General .

The Administration and Control Building will provide facilities for operating personnel, experimenters, and visitors. The building will be divided into the following basic functional areas or rooms:

Reception Room - The Reception Room will provide space for a receptionist and seating for visitors. An adjacent Display Area will provide an exhibit area for solar power-related displays, photographs," and models.

Administrative and Technical Offices - The offices will provide space for administrative functions to support the Solar Thermal Test Facility requirements and will include offices for facility personnel and experimenters.

Program Presentation and Conference Rooms - The Program Presentation Room will provide space for public and contractor solar test-related audio-visual programs and will include a projection room and program preparation room with a planned seating capacity of 56 persons. The Program Preparation Room will provide space for preparation of technical program presentations and storage of prepared programs. A conference rooni will be provlded for small administrative and technical conferences, experimenters, 
and facility personnel. The Projection Room will provide space for rear screen projectors, audio system, and a control desk.

Library - The Library will provide storage space for test reports, reference material, solar power-related periodicals, and file space for experimenters and facility personnel.

Laboratories - Two laboratories will be provided. One will be dedicated to instrumentation maintenance and calibration functions by permanent facility personnel, and the other will be dedicated to experimenter requirements.

Master Control/Computer Room - A master control/computer room will be provided for control console and computer equipment including control safety equipment. An uperator console will be located in a tower above the computer room to provide a 360degree view of the surrounding area with partirnlar attention givon to viewing lle levtelver tower, the lieliuslal fleld, and tèsts being conducted on the tower.

Observation Deck - An observation deck will be provided at the first floor roof level to permit observation of the receiver tower and heliostat field by visitors.

Passenger and Service Elevator - One passenger and service elevator will be provided for public and handicapped passenger use to the observation deck and the elevated operator console room.

J. Assembly Building

Ġeneral

The assembly building will house permanent facility personnel and experimenters for the purpose of assembly and checkout of collector subsystems, which are composed of heliostats and thetr control and drive mechanisms, and receiver subsystems, which consist of boiler/superheaters. Test assemblies for materials research and other areas of technology will be assembled in this , structure.

Office - The office will provide space for temporary and permanent persunnel associated with test assembly and checkout functions.

Laboratories - Two laboratories will be provided for experimenter use and will be maintained for the purpose of testing hardware, and maintaining instruments and controls. Laboratory activities such as chemical analysis of heat transfer fluids and nietallurgfual specimen studies will be conducted.

Assembly Areas - The experimenter assembly area will be required for preparation and checkout of research and subsystem hardware. Large exterior overhead type doors will be required for incoming and outgoing test assemhlies and ascooiatcd components. 
Machine Shop, Welding, and Storage - The machine shop, welding, and storage area will provide space for maintenance and minor modifications of equipment.

Space for welding, metal working, and woodworking equipment will be provided.

\section{Equipment}

Bridge Cranes - Two 9,070-kilogram (10-ton) capacity bridge cranes, traveling on the common rail system will be provided in the assembly areas. Hook height of each crane will be 50 feet.

Welding - 225 Amp Arc Welding Outfit.

Oxy-Acetylene Welding and Cutting Equipment.

Hydrostatic Test Equipment - Portable equipment for hydrostatic testing of test hardware will be available. 


\section{CHAPTER IV. REQUIREMENTS OF EXPERIMENTERS}

Tlie expertmenter will be required to provide documentation about his experiment. The information that may be required is described in this chapter. A summary list of requirements and their lead times are given on Table IV. These lead times must be met by the experimenter to assure that installation and operation schedules are met.

\section{TABLE IN}

Requirements for Experimenters

Experimenter Input to STTF

1. Discussions with $S T \cdot \bar{T} F$ staff

2. Data package and codes and standards input

3. Test plan

4. Instaliatinn, QA and chcclsout procedures

5. Operating procedures

6. Maintenance procedures

7. Operator training input

8. QA records, reports, and as-built drawings

y. Unpacking and receiving inspection

10. Manufacturer's drawings, literature, and manuals

11. Experiment rcmoval ard luandling
Minimum Lead Time Prior to Receipt of Experiment at STTF

II, $\mathrm{C}$

IV, $A \& B$

90 days

IV, C

90 days

IV, D, 1 .

60 days

V. ก. 2

GO days

IV, D, 3

60 days

IV, D, 4

60 days

II, $\mathrm{C}$ and $\mathrm{IV}, \mathrm{E}$

30 days

IV, D, 5

15 days

TV, D, 6

With hardware

IV, $\mathrm{D}, \mathrm{V}$ 


\section{A. Data Package}

All experiments must be documented. The information shall be submitted to the STTF by the experimenter in the form of a Data Package. Five copies, including drawings, are required. The Data Package shall cover the following aspects of the experiment. The exact contents and amount of detail required will be determined by the STTF-ECO.

\section{Scope and Objective}

This shall be a summary of the nature of the experiment, a summary schedule and test duration, operating conditions, and expected or desired results.

\section{Design Description}

This section shall describe the final design of the experiment. It may include:

1. Specifications and Design Criteria.

2. Drawings - Mechanical and Electrical.

3. Engineering analysis and calculations to demonstrate the integrity of the equipment during normal, abnormal, or emergency conditions. Design calculations and a summary of prior test experience may also be included.

4. STTF interface and thermal shielding considerations including any special designs or requirements.

5. Utility requirements.

6. Detailed bill of materials and a list of spare parts to be supplied with the experiments.

\section{Safety Analysis}

The experimenter's safety analysis shall identify all potential safety problems and failure modes for the experiment and possible hazards to personnel and to the STTF. The analysis shall include normal and faulted operating conditions, and natural hazards such as earthquakes, high winds, rain, snow, and hail. It shall list all normal and unique safety features and demonstrate that "fail-safe" concepts have been incorporated into the design, operating procedures, and sequences. The experimenter will be responsible for supplying this safety related information to the satisfaction of the STTF-ECO. The STTF staff will have full responsibility for overall safety during the test.

The STTF will operate with the following general safety rules that the experimenter should account for in the development of his own safety analysis.

1. Personnel will not be allowed in the heliostat field for the period starting one hour before and during solar operations. 
2. Personnel will not be allowed at the level of the tower where the experiment is being performed unless special protective equipment and safety policies are established. Personnel access to other parts of the tower will be reviewed for each experiment, but in general tower access will be discouraged.

3. Experiments should, whenever possible, be designed for remote operations and monitoring using the STTF digital control and data systems. Special experimenter needs will be accommodated whenever possible within the overall safety considerations of the STTF.

4. Personnel will normally be allowed to be in the mechanical/electrical equipment rooms at the base of the tower during solar operations.

Pronedureg

This section shall be descriptive procedures that cover the seruenre nf events requirch for the experiment. In addition, detailed, step-by-step procedures may be required 60 days in ad-

vance of the expected installation date for the experiment. Procedural input will be required from all experiments whether Sandia or the experimenter operates the equipment. The level of detail required will be determined by the ECO.

The descriptive procedures may include:

1. Assembly, installation, check-out. and pre-operational testing.

2. Normal operations.
a. Startup
b. Run
c. Shutdown

3. Abnormal operations.
A. Emergencies including loss of power, luss of solar flux, loss of coolant, and loss of utilities.
b. Kesponse to environmental effects such as earthquakes, storms, clouds. e.t.r.
c. Unique safety requirements and procedures.

4. Maintenance
a. Normal maintenance of all components.
b. Preventive maintenance and calibration requirements.
c. QA requirements and checkout or recalibration requirements shall be included.

5. Removal and disposition of experiment. 


\section{Quality Assurance}

This input outlines the experimenter's plan and procedures for providing quality assurance to the design and construction of the experimental hardware. It shall show how quality requirements will be met and how QA records will be kept (forms, etc.). The scope of $Q A$ requirements for installation of the equipment at the STTF shall be listed. A completed QA records document will be required at least 30 days prior to installation of the experiment.

\section{Supplementary Information}

The experimenter may be required to supply additional information including, but not limited to:

1. Operation and maintenance manuals for commercial components and instruments.

2. Spare parts lists (parts to be supplied by experimenter).

3. Functional wire list.

4. STTF/experiment interface drawings.

5. Special tool and equipment list.

6. Description of assembly facility needs.

\section{Data Package Changes}

Any design or other changes to an experiment after the Data Package is approved must be submitted to the STTF at the earliest possible date as an addendum to the Data Package. The addendum will also receive thorough review by the STTF staff and a separate approval. Normally, changes of any kind will lengthen the implementation schedule. Fajlure to notify the STTF of changes at an early date may also result in delays.

\section{B. Codes and Standards'}

It is realized that the STTF will test equipment and systems that are highly experimental in nature and that existing codes and standards may not be appropriate. After the feasibility of an experiment is initially established, the ECO will determine which codes or standards, if any, must be followed. If existing codes or standards cannot be strictly met (due to unconventional design or other reasons) the experimenter must demonstrate by calculations or by test data that the design and fabrication process to be used will provide a safe experiment.

The following detailed mechanical design documentation may be required with the Data Package depending on the nature of the experiment. Propriety designs, design methods, and fabrication methods will be protected.

1. Complete calculations with all assumptions, computer codes, and conclusions reached shall he dnọmmenter.t. 
2. Assumed static or dynamic loads, and load factors for normal and faulted conditions. Wind loads for gusts up to $100 \mathrm{mph}$ and earthquake loads ${ }^{*}$ for Zone 2 risk shall be included.

3. Assumed working stress and the factors of safety used shall be listed. Any unique temperature gradients or temperature cycles caused by the solar flux or experiment design must be considered.

4. Any applicable codes, standards, requirements, criteria, sources, references, and sources of test data or other data shall be listed.

The following are potentially applicable codes and standards.

Mechanical

1. ASME Code for Fired and Unfired Pressure Vessels and Relief Valves (applicable sectious).

2. ASME (or equivalent ASTM) Materials Specifications.

3. ANSI Code for Pressure Piping ( $\Lambda$ NSI-B31).

4. Compressed Gas Association Standạds.

5. Specification for Architecturally Exposed Structural Steel; American Institute for Steel Construction.

6. Specification for the Design, Fabrication, and.Erection of Steel for Buildings: ATSr.,

7. Occupational Safety and Health Standards (OSHA) 29CFR1910

\section{Electrical}

1. National Fire Protection Association Standardø (includes Natiunal Electrical Code).

2. OSHA 29CFR 1910

\section{C.. 'L'est Plan}

The experimenter's test plan will be used to allocate resources and establish schedules for the experintul. The input will be used to develop operating plans and procedures for the actual testing on the STTF. The test plan shall include:

1. The test matrix of the tlestred oct of values as a function of time for:
a. Temperature
b. Pressures
c. Solar flux distributions
d. Flow rates
e. Liquid levels.

* The STTF-ECO will supply earthquake response data for the appropriate location and test level on the STTF tower. 

f. Coolant chemistry
g. Environmental and weather conditions
h. Other parameters

2. The proposed implementation sequence and schedule shall be in the form of a chart or network-type sequence of events for implementation of the testing. The sequence should start with the shipment of hardware to the STTF and continue through removal and final disposition of the experiment. The ECO engineer will work with the experimentcr to develop an actual schedule after receiving the proposed sequence of activities.

3. Data acquisition, on-line computer analysis, and computer control needs for the experiment. (This must be a detailed list of data channel and control requirements developed in conjunction with the ECO engineer).

4. Special data needs from other STTF systems.

a. Heat rejection system.

b. Heliostat array

c. Real time aperture flux system.

d. Tower surface temperatures.

e. Meteorological data.

f. LBL circumsolar telescope.

\section{Detailed Procedures and Training Materials}

The experimenter may be required to provide the ECO detailed procedures for the operation and maintenance of the experiment. The amount of detail required will be determined by the ECO based on the nature of the experiment and how the experiment is to be implemented and operated. Five copies (including drawings) are required. The scope of the detailed input required may include:

1. System installation, QA requirements, and check-out procedures.

(60 days before receipt of hardware)

2. Start-up, operation, shut-down, and emergency procedures.

(60 days before receipt of hardware). Emergency procedures shall cover normal and faulted conditions and shall take the experiment and the STTF to a safe configuration.

3. Koutine and preventive maintenance procedures. (60 days before receipt of hardware)

4. Operator training procedures including dealing with all unique hazards. (60 days before receipt of hardware) 
5. Unpacking and receiving inspection procedures. (15 days before receipt of hardware).' Special needs for heavy equipment shall be submitted at least 30 days in advance.

6. Manufacturer's drawings, literature, and operating manuals for all commercial components. (To accompany hardware).

7. Experiment removal and post experiment handling procedures. (60 days before removal of hardware).

The above lead times are required to assure that the installation and operation schedule is achieved. The experimenter shall be able to consult with the ECO on the interfacing of the experiment procedures with the STTF master prorecures' The exporimontor may aloo be called on to proviide operator training sessions for the STTF operators.

\section{E. Quality Assurance Records}

So that the STTF-ECO can approve the shipment of the experimental hardware and make any final arrangements for any special interfaces, the experimenter shall submit two copies of their QA Records at least 30 days prior to the expected installation date. The contents of the QA Records will vary from experiment to experiment and will depend on specific requirements for quality and safety that are related to the potential hazards and required reliability of the experiment. The contents of the QA Records will be determined by the STTF-ECO at the time the Data Package is approved. The QA Records in all cases will include as-built drawings:

1. Mechanical (including interfaces).

2. Electrical (including data and control links).

The QA Records may also include:

1. Mechanical design documentation:

2. Non-destructive examination procedures and data:

3. Certified tést reports.

4. Welder certification records.

5. Muterials cerlifications.

6. List of archive materials (to be held by experimenter).

7. Code-stamp certifications if required.

8. Other $\mathrm{QA}$ information.

The ECO will review and audit the submitted information. Any serious discrepancies, unexpected design or fabrication changes, or omissions will be brought to the attention of the experimenter and corrective action by the experimenter and additional ECO reviews may be required 
prior to granting permission to ship the hardware to the STTF. Two to four weeks will normally be required for the review and approval process of $\mathrm{QA}$ Records that is complete and in order.

\section{F. Shipping and Receiving}

The experimenter will be responsible for shipping his experiment prepaid to the STTF site. Shipment shall only be made after the QA Records are approved. He shall follow all appropriate DOT, FAA, or IATA standards for crating, packing; rigging, and shipping. The shipment should be addressed as follows:

Solar Thermal Test Facility

Division 5713 - T27

Sandia Laboratories

Attn: STTF Assembly Facility (X2280)

Albuquerque, NM 87115

Receiving inspection shall be performed by Sandia and the resident experimenter, if present. Shipping damage, if any, shall be rectified by the experimenter.

If the experiment is to be returned to the experimenter at the end of the test program, all costs and arrangements shall be made by the experimenter. Otherwise, the experiment shall become the property of ERDA.

\section{G. Results and Reports}

The STTF staff will publish general reports related to operation of the STTF and summary reports on the operation of all experiments. Private or proprietary designs and data will be appropriately protected.

The, STTF staff may be considered as contributing co-authors with the experimenter of certain open litcrature reports or publications resulting from tests at the STTF. The actual preparation of joint reports and publications will be shared responsibility. 
STTF User's Association (200)

First National Bank Bldg. East Suite 1507

Albuquerque, NM 87108

Attn: Executive Director

US Department of Energy (3)

Albuquerque Operations Office

P.O. Box 5400

Albuquerque, NM 87115

Attn: G. Rhodes

J. Robertson

G. Papas

UE Department of Dnergy (5)

Division of Jolar Inergy

Washington, DC 20545

Attn: G. M. Kaplan

C. W. Butur

H. H. Marvin

R. H. Fields

C. Castellans

Ford Motor Company

P. D. Box 2053

Dearborn. MI 48121

Attn: T. Cole. Manager

Chemical Scientific Research Staff

Solar Energy Laboratory

University of Houston

Houston, TX 77004

Attn: A. F. Hildebrandt, Director

The Journal.

University of New Hampshire

Kingsbury Hall - 247

Durham, NH 03824

Attn: F. K. Manasse, Editor in Chief

General Atomics Company

P. O. Box 81608

San Diego, CA 92138

Attn: J. L. Russell

New Mexico State University

Box 3449

Las Cruccs. NJM mnก?

Attn: R. L. San Martin

Rockwell Interrualional

Atomics International Division

8900 De Soto Avenue

C'ànóga Yark, CA Y y304

Attn: T. Springer

Proj. Mgr., Energy Systems
Engineering Experiment Station

Georgid Institute of Technology

Atlanta, GA 30332

Attn: J. D. Walton, Jr.

5334 B. D. Zak

5334 P. J. Brànnon.

5700 J. Scott

5710 G. Brandvold (2)

5710 L. Wetherholt

5710 R. L. Manhart

5711 J. F. Banas

5712 J. A. Leonard

5713 J. V. Otts (202)

5713 O. E, Arvizu

3713 . O. B. Mavis

5713 J. T. Holmes

5713 ก. .T. Kuehl

5113 L. K. Matthews

5713 L. G. Seamons

5713 J. M. Stomp

5713 R. D. Aden

5714 R. P. Stromberg

5715 R. H. Braasch

5719 D. G. Schueler

8130 R. C. Wayne

8131 W. G. Wilson

8132 A. C. Skinrood

8132 T. D. Brumleve

8132 C. L. Mavis

8132 W. C. Muore

8132 C. T. Yokomizo

8132 E. English

9344 . D. M. Darsey

8266 D. A. Aas

3141 C. A. Pepmtueller (Actg) (5)

3151

W. L. Garner (3)

For DOE/TIC (Unlimited Release) 